Eikón Imago

e-ISSN: 2254-8718

\title{
Análisis iconográfico de la portada del Templo de los Santos Reyes de Metztitlán, Hidalgo
}

\author{
Carmen Fabiola Moreno Vidal ${ }^{1}$
}

Recibido: 02/05/2018 / Aceptado: 10/11/2018 / Publicado: 15/11/2018

Resumen. La portada del templo de Metztitlán, posee una rica decoración en base a elementos vegetales y animales, ambos con una fuerte carga simbólica y un mensaje dirigido a exaltar la gloria de Cristo y la relación espiritual con los goces de la vida eterna a través del bautismo, en la decoración también se refleja el pensamiento evangelizador de la orden agustina, que fue la primera en establecerse en la Sierra Alta de Hidalgo. Esta portada también presenta en su decoración varios símbolos pertenecientes al mundo indígena y que están relacionados con los astros, cuya posición en el firmamento regía su ritualidad, por lo que era importante situarlos de forma velada y como parte decoración en zonas importantes de la portada. En este artículo hemos tratado de hacer un análisis del simbolismo de los principales elementos que conforman la portada, tanto de los elementos que pertenecen al mundo cristiano, como al indígena, y que lograron integrarse y complementarse entre sí, pudiendo transmitir un mensaje comprensible tanto para evangelizadores, como para evangelizados.

Palabras clave: Portada, Metztitlán, agustino, xonecuilli, citlaltlachi, granada, rosa, números.

\section{[en] Iconographic analysis of the front of the Temple of the Holy Kings of Metztitlán, Hidalgo}

\begin{abstract}
The facade of the Metztitlán temple, has a rich decoration based on plant and animal elements, both of them with a strong symbolic load and a message aimed at exalting the glory of Christ and the spiritual relationship with the joys of eternal life through baptism, in the decoration the evangelizing thought of the Augustinian order is also reflected, which was the first to establish itself in the Sierra Alta de Hidalgo. This facade also presents in its decoration several symbols belonging to the indigenous world and which are related to the stars, whose position in the firmament governed their rituality, so it was important to place them in a veiled form and as part decoration in important areas of the façade. In this article we have tried to make an analysis of the symbolism of the main elements that make up the facade, both of the elements that belong to the Christian world, as to the indigenous, and that managed to integrate and complement each other, being able to transmit a comprehensible message for both evangelizers and evangelized.
\end{abstract}

Keywords: Facade, Metztitlán, Augustinian, Xonecuilli, Citlaltlachi, pomegranate, rose, numbers.

Sumario. 1. Antecedentes Históricos. 2. Ubicación geográfica. 3. Fundación del convento de los Santos Reyes de Metztitlán. 4. Características del conjunto conventual. 5. Portada de templo. 5.1. León. 5.2. San Pedro y San Pablo. 5.2.1. San Pedro. 5.2.2. San Pablo. 5.3. Pera. 5.4. Durazno. 5.5. Granada 5.6. Pez. 5.7. Flores. 5.7.1. Nahui-Ōlin. 5.8. Números. 5.8.1. Uno. 5.8.2. Tres 5.8.3. Cuatro. 5.8.4. Cinco. 5.8.5. Ocho. 5.8.6. Diez 5.8.7. Veintisiete. 5.9. Rosa 5.10. Querubines. 5.11. Trisagio. 5.12. Niño Salvador del

1 Instituto Nacional de Antropología e Historia (INAH), México.

Email: fabula2002@hotmail.com 
Mundo. 5.13. Ángeles músicos 5.14. Xonecuilli. 5.15. Citlaltlachi. 5.16. Felino. 5.17. Ave. 6. Reflexión final. 7. Bibliografía.

Cómo citar: Moreno Vidal, Carmen Fabiola (2018), “Análisis iconográfico de la portada del Templo de los Santos Reyes de Metztitlán, Hidalgo”, Eikón Imago 13, 79-122

\section{Antecedentes históricos}

El Municipio de Metztitlán deriva su nombre de las raíces nahuas, metztli, "luna" y tlan "lugar", que significa "lugar de luna"2. La ubicación geográfica de Metztitlán confería una situación especial para el asentamiento de los grupos humanos. La fertilidad de sus tierras, la abundancia de agua, la posición estratégica que le da cierto grado de defensa y en especial el paso natural que unía la región norte de la Huasteca y el Golfo con la región sur del Altiplano (vía por la que se realizaron invasiones, migraciones y comercio), fueron elementos suficientes para que el hombre ocupara esta área desde tiempos muy remotos. La búsqueda de los mexicas por conquistar Metztitlán se debió, seguramente, a su interés de expansión hacia el Golfo. También los pueblos costeños buscaron invadir Metztitlán para dirigirse al altiplano central, ya que Metztitlán constituyó un importante cruce de caminos y paso obligado a diferentes rutas $^{3}$.

Con la caída de Tula, aproximadamente en el año de 1250, se produjo una dispersión de la población, situación que aprovecharon los grupos chichimecas recolectores-cazadores, que merodeaban en la frontera del poderío tolteca, para ocupar las tierras de este, introduciendo una cultura inferior a la región poblada antiguamente por los pueblos de alta cultura mesoamericana ${ }^{4}$.

Lo cierto es que Metztitlán fue un área muy poblada con gran heterogeneidad racial y cultural, donde los otomíes, huastecos, chichimecas, totonacas, nahuas y tepehuas convivían, en especial, debido a la riqueza de los recursos y a la fertilidad agrícola de la Vega ${ }^{5}$. La región de Metztitlán se consideró "zona de refugio", como un lugar remoto e inaccesible que acogía a grupos que huían del yugo tepaneca ${ }^{6}$ y posteriormente mexica.

Los enemigos de Metztitlán fueron Tenochtitlan, Tlaxcala y la Huasteca, además de Atotonilco el Grande, Ixmiquilpan, Actopan, Chapulhuacán y Huayacocotla y Huejutla. Los metzcas lograron defenderse de todos estos enemigos y por las guerras

2 Secretaría de Gobernación, Gobierno del Estado de Hidalgo. (2010). Enciclopedia de los municipios y Delegaciones de México, Estado de Hidalgo [En línea]. México: Instituto para el Federalismo y el Desarrollo Municipal. Disponible en

[http://www.inafed.gob.mx/work/enciclopedia/EMM13hidalgo/municipios/13037a.html] consultado el 14 de agosto de 2017.

3 Lorenzo Monterrubio, Carmen, El lugar de la luna, Metztitlán en el siglo XV, México, Instituto de Artes, Universidad Autónoma del Estado de Hidalgo, 2003, p.22.

4 Carrasco, Pedro, Los Otomíes. Cultura e Historia prehispánica de los pueblos mesoamericanos de habla otomiana, México, Gobierno del Estado de México, 1986, p. 242.

5 Esta se ubica al fondo de la barranca de Metztitlán, tiene un largo aproximado de $100 \mathrm{~km}$ y esta irrigada por el rio Grande o Tulancingo.

6 Nombre de uno de los pueblos prehispánicos, de origen chichimeca que se instaló en la Cuenca de México a mediados del siglo XII de nuestra Era. 
que tuvieron "los tenían por gente de mucho valor y esfuerzo. Y siempre fue reino por sí, nunca sujeto a Moctezuma ni a otro señor, hasta que llegaron los españoles",7.

En tiempos prehispánicos Metztitlán fue un poderoso señorío con fama de invencible y posterior a la llegada de los españoles la región fue sumamente codiciada, tanto por su riqueza natural que generaba la Vega como por su numerosa población indígena.

Finalmente se consumó la conquista de Metztitlán por los españoles, que por mucho tiempo había resistido a sus enemigos. A mediados de 1524 terminó la resistencia cuando el ejército español después de varias batallas redujo la zona, sin embargo, los chichimecas no se sometieron y todavía atacaban la zona en la década de $1580^{8}$. Después de la conquista, el famoso Señorío prehispánico de Metztitlán fue sojuzgado y la población otomí explotada brutalmente por medio de la encomienda.

\section{Ubicación geográfica}

El municipio de Metztitlán se encuentra en el estado de Hidalgo, a 81 kilómetros de distancia de Pachuca y 175 kilómetros de la ciudad de México. A una altura promedio de 1,264 metros sobre el nivel del mar ${ }^{9}$. Presenta un clima templado-súbcálido, el cual registra una temperatura anual de $20.2^{\circ} \mathrm{C}$.

El Municipio se encuentra ubicado en su totalidad en la Sierra Madre Oriental, en su mayor parte formado por sierra y en menor proporción por cañones, lomeríos y mesetas; en una pequeña parte se localiza en el eje neovolcánico; formado por llanuras; el $60 \%$ está formado por pendientes mayores al $15 \%{ }^{10}$.

\section{Fundación del convento de los Santos Reyes de Metztitlán}

En el año de 1536 comenzó el avance septentrional de los frailes agustinos a la región otomí y a la Sierra Alta, que incluía a Metztitlán. Al celebrar en ese año la reunión en Ocuituco, se determinó la ruta de avance y se designó a Fray Juan de Sevilla y a Fray Antonio de Roa para preparar esta incursión. El padre Roa se quedó en Molango, mientras que Sevilla se estableció en Metztitlán de 1536 a $1542^{11}$.

El cronista Juan de Grijalva da cuenta de la dificultad de emprender la nueva empresa evangelizadora en la región: "porque el puesto era inaccesible, o ya por lo

\footnotetext{
7 Acuña, René (ed.), "Relación de la Alcaldía Mayor de Metztitlán y su Jurisdicción, 1579”, en Relaciones Geográficas del siglo XVI: México. Tomo segundo. UNAM. México. 1986. p. 67.

8 Gerhard, Peter, Geografía histórica de la Nueva España, 1519-1821, México, Universidad Nacional Autónoma de México, 1986, p. 189.

9 Municipios.mx. (2018). Hidalgo. Metztitlán. [En línea]. México: Todos Los Municipios de México. Disponible en [http://www.municipios.mx/hidalgo/metztitlan/] consultado el 23 de abril de 2018.

10 Gobierno del Estado de Hidalgo. (2002). Enciclopedia de los Municipios de México. Estado de Hidalgo. Metztitlán. Medio Físico. [En línea]. México: Instituto Nacional para el Federalismo y el Desarrollo Municipal. Disponible en

[http://intranet.e-hidalgo.gob.mx/enciclomuni/municipios/13037a.htm] consultado el 23 de abril de 2018.

11 Lorenzo Monterrubio, op.cit., p. 89.
} 
profundo, o ya por las cumbres, porque aquellas sierras tocan en los extremos: los indios bárbaros y desencuadernados: los demonios muchos ",12.

La Comunidad fue la primera construcción agustina del lugar, estaba constituido por un templo de nave única, un atrio bardado y almenado al sur, y al poniente, el resto de dependencias conventuales. De acuerdo con la historia de Fray Juan de Sevilla, esta se estaba construyendo hacia 1537. Un par de años más tarde, aun antes de concluirse tuvo que ser abandonado por una devastadora inundación que obligó a los religiosos a buscar las partes más altas del cerro ${ }^{13}$, aunque la historia de la gran inundación que sufrió la Vega en 1539 no es del todo aceptada ${ }^{14}$. En 1541, año en el que la población fue elevada al rango de priorato, este pequeño edificio era insuficiente para las actividades que debían desarrollarse en una cabecera de doctrina, por lo que se determinó levantar un nuevo convento. Esta primera construcción no fue abandonada y continuó siendo usada como local de servicios del convento mayor ${ }^{15}$.

El convento de los Santos Reyes en Metztitlán, fue reconocido como un gran centro de campo misional, siendo un priorato ${ }^{16}$ de donde se visitaban ${ }^{17}$ los pueblos de los alrededores. Los gastos de su construcción recayeron, en un principio, en el encomendero o la Corona, pero la Real Cédula dada en 1552 incorporó a la Real Hacienda y a los indígenas ${ }^{18}$.

Es importante señalar que en un principio, los indígenas aportaban voluntariamente productos de la tierra para sustentar a los frailes, sin embargo, esta limosna se convirtió con el paso del tiempo en una obligación, que los afectaba directamente.

En realidad, los indígenas no entendían el mensaje que ofrecían los frailes, ya que por un lado se salvaba el espíritu, y por el otro se esclavizaba el cuerpo. A pesar de los esfuerzos de los frailes para que los indígenas aceptaran la nueva religión, era difícil

12 Grijalva, Juan de. Crónica de la Orden de N. P. S. Agustín en las Provincias de la Nueva España. Editorial Porrúa. México. 1985, p. 99.

13 Ayuntamiento Digital. (2014). Convento de los Santos Reyes. [En línea]. México: Honorable Ayuntamiento Municipal de Metztitlán. Disponible en

[http://metztitlan.gob.mx/turistico/Contenido.php?seccion=2\&lat=681]

14 Victoria, José Guadalupe. Arte y Arquitectura en la Sierra Alta. Siglo XVI. UNAM. México. 1985. p. 83.

15 Artigas, Juan Benito, Metztitlán Hidalgo: Arquitectura del siglo XVI, Universidad Nacional Autónoma de México, 1996, p. 64.

16 El priorato era la base de toda la estructura política, social y económica de la orden y se constituía como cabecera de doctrina, rodeado de pueblos dispersos que constituían visitas, a los que asistían los frailes del convento central a impartir los sacramentos y la doctrina cada determinado tiempo. En sí, un priorato era un "conjunto conventual donde residían varios religiosos bajo las órdenes de un prior". Metztitlán fue priorato (junto con Molango y Tlanchinol) y desde aquí incursionaban hacia diversos rumbos a los pueblos de visita, donde dirigieron la construcción de pequeñas iglesias que fueron modificando al pasar de los años. Fueron visitas: santa María Xoxoteco, Mezquititlán, Zacualtipan, etc. Seis religiosos tenían a su cargo una red de 110 feligresias. Tochtli. (2006). Meztli Azul [En línea]. México: Metztitlan, Hidago. Disponible en http://metztliazul.blogspot.mx/2006/12/metztitlan-hidalgo-mxico.html

17 En el caso de Metztitlán, los pueblos fueron visitados por dos frailes que iban en direcciones opuestas, decían misa y administraban los sacramentos. Al terminar, estos religiosos regresaban a su convento y salían otros dos a recorrer el mismo camino. Estos religiosos salían "predicando, bautizando, confesando, casando, dando extremaunción y a pocos dan eucaristía".

18 Rubial, Antonio. El Convento Agustino y la Sociedad Novohispana (1553-1630). UNAM. México, 1989, p. 175-176. 
que estos abandonaran sus antiguos dioses y ritos, es por esto que veladamente ofrendaban a diversas deidades materializadas en ídolos, que escondían o guardaban en cuevas o lugares sagrados. Finalmente lo que se logró fue un sincretismo religioso, en el que se fundían las deidades prehispánicas con santos cristianos ${ }^{19}$.

\section{Características del conjunto conventual}

El conjunto conventual de los Santos Reyes está ubicado en la cumbre de la montaña sobre la que se asienta la población de Metztitlán. Es una construcción que reúne todas las características arquitectónicas del siglo XVI novohispano: cuenta con un atrio, cruz atrial, templo, convento, capillas abiertas y capilla posa.

$\mathrm{El}$ atrio es de planta rectangular en forma de L, delimitado por una barda de mampostería almenada. Las entradas al recinto son tres: la primera se localiza en la parte sur, no tiene estructura de arcada y es solo una abertura en el muro, pero se jerarquiza por dos pilares rectangulares almenados y escudos circulares a los lados. En uno de los pilares aparece la siguiente inscripción: "A 24 de diciembre de 1722 años", fecha que puede indicar alguna remodelación en el convento. La segunda y tercera entradas también se estructuran como simples aberturas en el muro atrial; la segunda, se halla en el testero oeste y constituye el acceso más directo a las capillas abiertas; la tercera está ubicada en la barda este ${ }^{20}$.

En la primera etapa constructiva, contemporánea al convento de la comunidad o quizás inmediata a la designación de Metztitlán como priorato, se realizó la primera capilla abierta con sacristía anexa, el recinto atrial y las capillas posas, de las cuales quedan restos de dos de ellas en la esquina sureste y sobre la barda poniente del atrio $^{21}$.

La segunda etapa constructiva está constituida por la iglesia, el convento y la segunda capilla abierta, como lo demuestra el remate de almenas de su costado poniente, su mayor altura en relación con la primera capilla y su decoración pictórica más cuidada ${ }^{22}$.

La etapa más reciente corresponde al siglo XVIII (posiblemente se concluyó en el año 1722 como indica la inscripción de la entrada principal al atrio), momento en el que probablemente se realizaron los nichos adosados al muro del templo y su arcada transversal, así como la capilla noroeste del atrio que funcionó como recinto para velar los muertos que habrían de ser velados en el atrio ${ }^{23}$.

\footnotetext{
19 Uchamny, Eva A. "De algunos cristianos nuevos en la conquista y colonización de la Nueva España”. Estudios de Historia Novohispana. Vol. VIII. UNAM. México. 1985, p. 4.

20 Espinosa Spíndola, Gloria, Arquitectura de la Conversión y Evangelización en la Nueva España durante el Siglo XVI, Universidad de Almería, Servicio de Publicaciones 1999, Almería, p. 39.

$21 \quad$ Ibídem, p. 8990.

22 Artigas, op.cit., p. 91.

23 Espinosa Spíndola, Gloria, op.cit.
} 


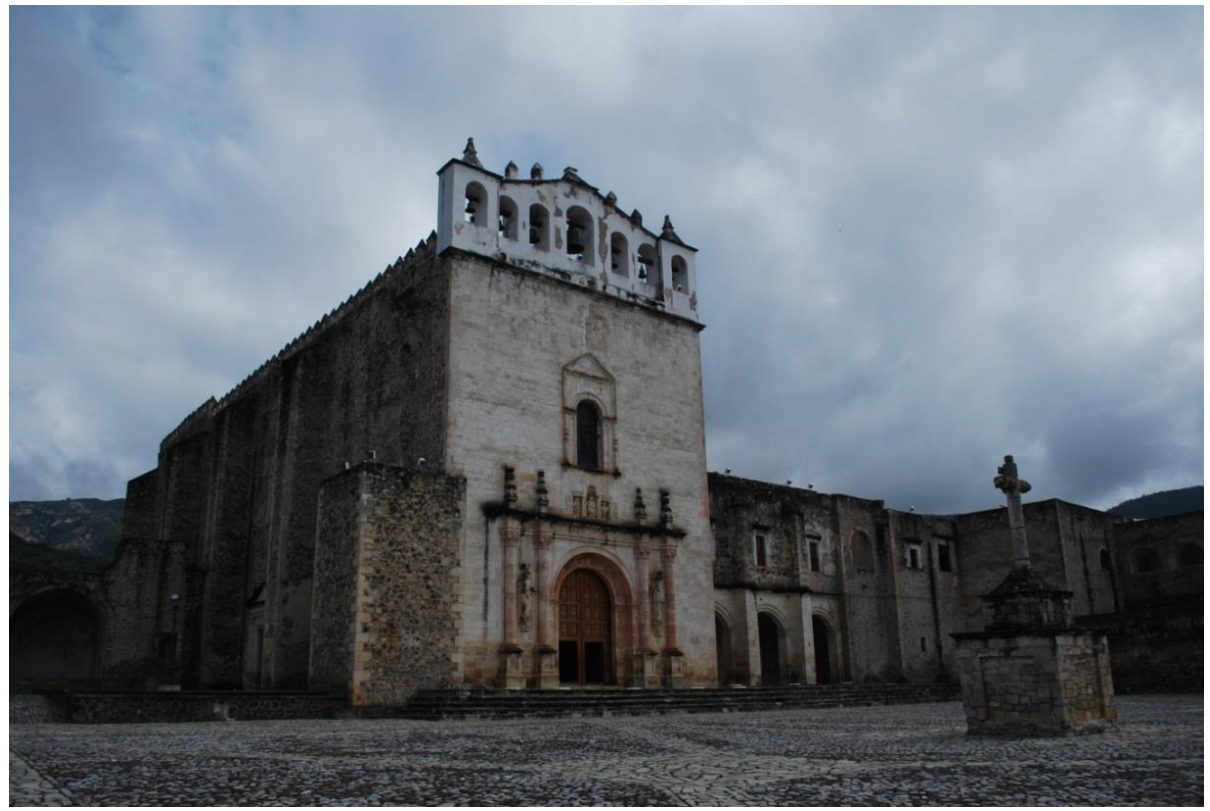

Fig. 1. Conjunto conventual de los Santos Reyes de Metztitlán.

Fotografía de Fabiola Moreno Vidal.

El templo presenta una severa imagen de fortaleza, con elevados muros coronados por almenas, escasas ventanas y macizos contrafuertes. Su fachada es de estilo plateresco con una composición similar a la del templo de Acolman en el estado de México. La fachada se remata con una gran espadaña de siete claros, que le da gran realce al conjunto.

El interior de la iglesia es de sumo interés, tanto desde el punto de vista arquitectónico, como por la riqueza artística que resguarda, principalmente los cinco retablos dorados de finales del siglo XVII y principios del XVIII. La planta de la iglesia es rectangular, mide 60 metros de largo por 12.80 de ancho, está cubierta con una bóveda de cañón corrido dividida en tres secciones: en el espacio que corresponde al ábside, la cubierta se solucionó con una bóveda abocinada con casetones rectangulares; el presbiterio, presenta una elegante bóveda de crucería cuyos plementos o nervios descargan los empujes sobre las pilastras del arco triunfal y las impostas del arco del ábside. La bóveda del sotocoro está limitada por un arco escarzano y nervaduras diagonales que descansan sobre columnas medias muestras de capitel compuesto, está decorada con grutescos y querubines.

Los muros de la nave presentan un ancho friso decorado con roleos vegetales y niños desnudos que enmarcan emblemas de la orden agustina y el pontificado representado por la tiara papal. Otro friso se conserva debajo de la cornisa o imposta que corre por el presbiterio y el ábside del templo.

Metztitlán es también uno de los conjuntos religiosos de la Sierra Alta que cuenta todavía con una gran extensión de pintura mural, en el convento esta está distribuida entre frisos, cenefas y guardapolvos, así como todo un interesante programa pictórico 
discursivo cuya temática trasmite el discurso filosófico y didáctico vinculado con la doctrina de la orden fundada por San Agustín.

El convento se compone, por el portal de peregrinos que da acceso al claustro, formado por pasillos o deambulatorios, separados del patio por arquerías con arcos peraltados en planta baja y de medio punto en planta alta. Los corredores o deambulatorios de ambos niveles, se encuentran cubiertos con bóvedas de cañón corrido decoradas en su totalidad con diseños provenientes de esquemas de Sebastián Serlio. Las esquinas están cubiertas por bóvedas de nervadura. Los vanos que se abren en el claustro bajo comunicaban a la iglesia, antesacristía, escalera, despensa, refectorio, patio de servicio y huerta; en el muro del templo, están los confesionarios abiertos en el propio muro. Los vanos del claustro alto, comunicaban con el antecoro, el deambulatorio interior que comunicaba a las celdas de los frailes y el correspondiente a la escalera que da acceso a la planta alta, se encuentra ubicada en su costado norte y consiste en un cubo rectangular cubierto con bóveda de cañón ${ }^{24}$.

La sacristía, unida al muro oriente, está precedida por la antesacristía, que comunica con la nave y los corredores del claustro tiene, además, la sacristía, una ventana al oriente y una puerta que, pasando por un pequeño departamento destinado a la bóveda, conduce al patio posterior ${ }^{25}$.

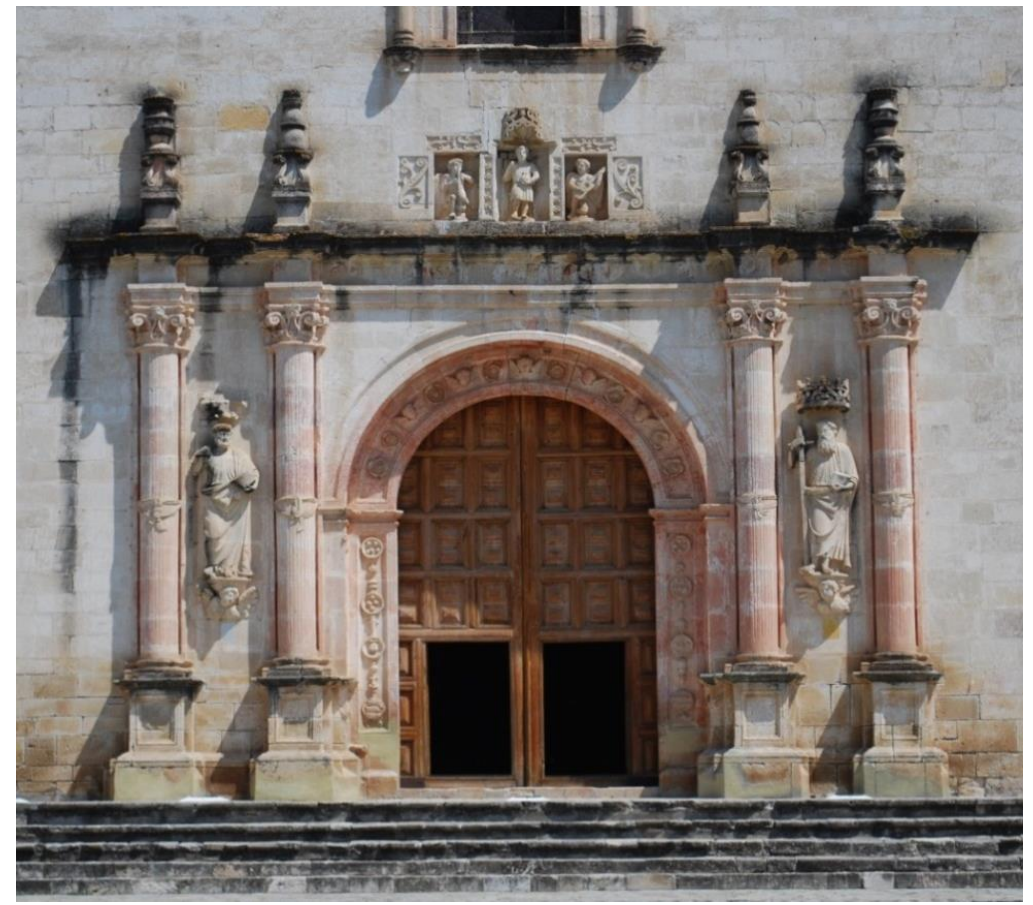

Fig. 2. Portada del templo de los Santos Reyes de Metztitlán.

Fotografía de Fabiola Moreno Vidal.

\footnotetext{
24 Fernández, Justino, Arte Mexicano. De sus orígenes a nuestros días, México, Editorial Porrúa, 1975, p. 55.

25 Ibídem
} 


\section{Portada del templo}

La composición de la portada de Metztitlán es muy similar a la de Acolman, en el Estado de México, diferenciándose de esta por los diseños en las jambas de frutas y peces y las rosas y querubines sobre el arco de ingreso, sin embargo Metztitlán es de una mayor sobriedad ornamental, como lo indica George Kubler en su libro: “Arquitectura Mexicana del siglo XVI". Según la hipótesis del historiador de arte Luis Javier Cuesta Hernández ambas fachadas son obra del arquitecto español Claudio de Arciniega, quien llegó a la Nueva España en 1554, siendo el convento de Acolman el primer edificio agustino en el cual intervino, entre 1558 y 1560. Ambas portadas, la de Acolman y la de Metztitlán, presentan similitudes formales con la fachada de la universidad de Alcalá de Henares en España, realizada por Arciniega entre 1542 y 1547 , así como otros elementos decorativos procedentes de la arquitectura sevillana y toledana que Arciniega utilizó en ciertos edificios novohispanos ${ }^{26}$.

La portada del templo es bella y elegante, su estilo plateresco lo subrayan un par de medias columnas a cada lado, sobre altos pedestales, poseen fuste estriado rodeado por un lazo anudado a mitad el fuste, sus capiteles son compuestos y presentan al centro una pequeña cabeza de león. En los intercolumnios se sitúan las esculturas de san Pedro a la izquierda y san Pablo a la derecha, cada uno sobre una peana cónica sostenida por un querubín, están cubiertos por doseletes coroniformes.

El vano de acceso al templo está enmarcado por dobles jambas con fustes cajeados y arcos de medio punto, estos están remetidos con respecto al paño de la fachada formando una arquivolta. Las jambas están decoradas con cuatro platos de frutas y peces cada una y presentan diferencias entre ellas en el número y tipo de frutas que componen cada plato, de arriba hacia abajo: la de la izquierda en su primer plato contiene cinco peras, el segundo cuatro duraznos, el tercero una granada y el cuarto tres peces, la jamba de la derecha en su primer plato contiene cuatro duraznos, en su segundo hay cinco peras, en su tercer plato tres peras: una grande al centro y dos pequeñas e invertidas a los lados, en su cuatro plato hay tres peces. La cara interna de las jambas también es cajeada y está decorada con flores de cuatro pétalos en número de diez por lado. El arco está decorado con ocho rosas intercaladas con cinco cabecitas de querubines, el intradós posee en su decoración veintisiete flores de cuatro pétalos, en las cuales se puede apreciar restos de pintura azul, amarilla y roja.

La cara interna que se forma a manera de arquivolta y que rodea el vano de acceso al templo también está constituido por pedestales cajeados que son una continuación de los que soportan las columnas de la portada, el pedestal de la izquierda está decorado con una cabeza de felino y el de la derecha tiene una cabeza de ave, ambos sostienen unos lazos y racimos de frutas, a continuación se encuentran las jambas cajeadas, la de la izquierda está decorada con racimos de frutas, volutas y un cartel conteniendo una flor, la de la derecha la conforman una guirnalda de flores, un racimo de frutas, un par de volutas más grandes que las de la izquierda y un cartel vacío, cabe

\footnotetext{
26 Cuesta Hernández, Luis Javier, "Sobre el estilo arquitectónico en Claudio de Arciniega. Su participación en la construcción de los conventos agustinos de Acolman, Actopan y Metztitlán. Su papel en la arquitectura novohispana del siglo XVI", Anales del Instituto de Investigaciones Estéticas, UNAM, número 76, 2000, pp. 61-88.
} 
mencionar que todos estos elementos están unidos por una especie de balaustre decorado.

Sobre los dos pares de columnas descansa un sencillo entablamento, en cuyo friso está inscrito el trisagio: "SANCTUS DEUS, SANCTUS FORTIS, SANCTUS INMORTALIS", sobre la cornisa y rematando las columnas se ubican elegantes flameros o pebeteros soportados por pedestales y volutas en forma de $\mathrm{S}$.

Sobre la cornisa y siguiendo el eje del vano de ingreso, se ubican tres pequeños nichos rectangulares, en una composición denominada serliana ${ }^{27}$, que resulta, en el del centro que es ligeramente más alto y que se cubre con un dosel en forma de concha, se ubica la escultura del Niño Jesús Salvador del Mundo, está flanqueado por dos franjas conteniendo cinco flores de cuatro pétalos, imagen del Nahui-Ōlin, estas franjas representan a la constelación prehispánica citlaltlachtli. En los nichos de los lados se ubican dos ángeles músicos; estos están enmarcados por volutas fitomorfícas, símbolo de la constelación prehispánica xonecuilli, dos pares en la parte superior y una a cada lado, así como en el dosel que cubre la parte central.

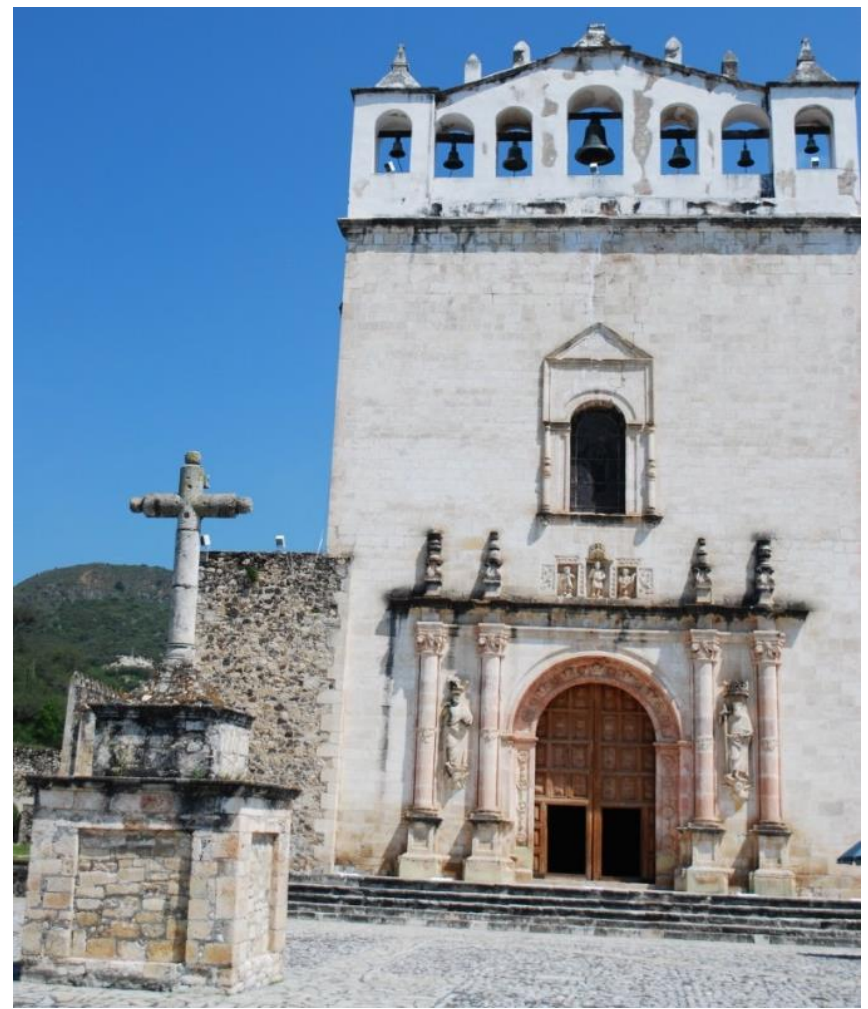

Fig. 3. Fachada del templo de los Santos Reyes de Metztitlán, con la ventana coral y la espadaña. Fotografía de Fabiola Moreno Vidal.

Recurso compositivo que resulta de dividir un hueco en tres partes, simétricamente, de manera que la parte central queda cubierta por un arco y es de mayor amplitud que las dos laterales, que se cubren mediante dinteles. Se llama así porque fue recogida y divulgada en el siglo XVI a través de los grabados del Tratado de Sebastián Serlio. 
Por encima de los nichos se encuentra la ventana del coro, la cual está conformada por un vano con arco de medio punto enmarcado por jambas y arco cajeados. La imposta que la divide horizontalmente marca los capiteles de las dos esbeltas columnas abalaustradas que descansan en una delgada moldura horizontal, saliente, sostenida bajo los balaustres con diminutos pinjantes. De la imposta hacia arriba se marca el rectángulo del alfiz que está coronado por un frontón triangular.

Por encima de la portada y rematando la composición se encuentra una gran espadaña de siete vanos con sus respectivas campanas, característica de la arquitectura de la orden agustina en la región. La espadaña a su vez estaba coronada con una cruz sobre la bola del mundo en llamas, actualmente solo están las almenas en número de cuatro y dos pináculos a los lados, que hace que la construcción sobrepase los treinta metros de altura ${ }^{28}$.

\subsection{León}

Los capiteles de las cuatro columnas que flanquean la portada del templo están decorados en su parte central con cabezas de leones que sostienen unos lazos con el hocico.

En el caso de Metztitlán el león representa a Cristo resucitado ya que en la edad media se creía que los cachorros de león nacían muertos y que al tercer día su padre los resucitaba por medio de su aliento, entonces la muerte aparente de los pequeños leones representa la estancia de Jesucristo en el sepulcro y que al tercer día resucita de entre los muertos. El león también puede representar a Cristo vigilante debido a la antigua creencia de que el león dormía con los ojos abiertos, así se vio la imagen del Cristo atento que todo lo ve y que guarda del mal las almas, como un pastor vigilante $^{29}$.

La imagen del león simbolizando Cristo en la tradición cristiana, está relacionada con el término de "León de Judá", en tanto que Jesús era integrante de la Tribu de Judá y en el Nuevo Testamento se le menciona como "perteneciente a la tribu de David" ${ }^{\prime 3}$. Similar expresión se emplea en el libro del Apocalipsis para designar a Jesús: "Entonces uno de los ancianos me dijo: «No llores, porque el León de la tribu de Judá, la raíz de David, ha vencido para abrir el libro y desatar sus siete sellos". ${ }^{31}$

\footnotetext{
28 Documental fotográfico en técnicas alternativas de la arquitectura del siglo XVI de Hidalgo. (2012). Ex Conventos de Hidalgo México [En línea]. México. Disponible en [http://132.248.9.195/pd2008/0624429/A6.pdf] consultado el 25 de enero de 2017, p.40

29 Charbonneau-Lassay, L., El bestiario de Cristo, simbolismo animal en la antigüedad y la edad media. Vol. I, traducción de Francesc Gutiérrez, Barcelona, Sophia Perennis, 1997, p. 144.

30 Beker, Udo, Enciclopedia de los símbolos. Ed. Swing, Barcelona, 2008, pp.179-180.

$31 \quad$ Apocalipsis 5:5; Versión Reina-Valera 1988
} 


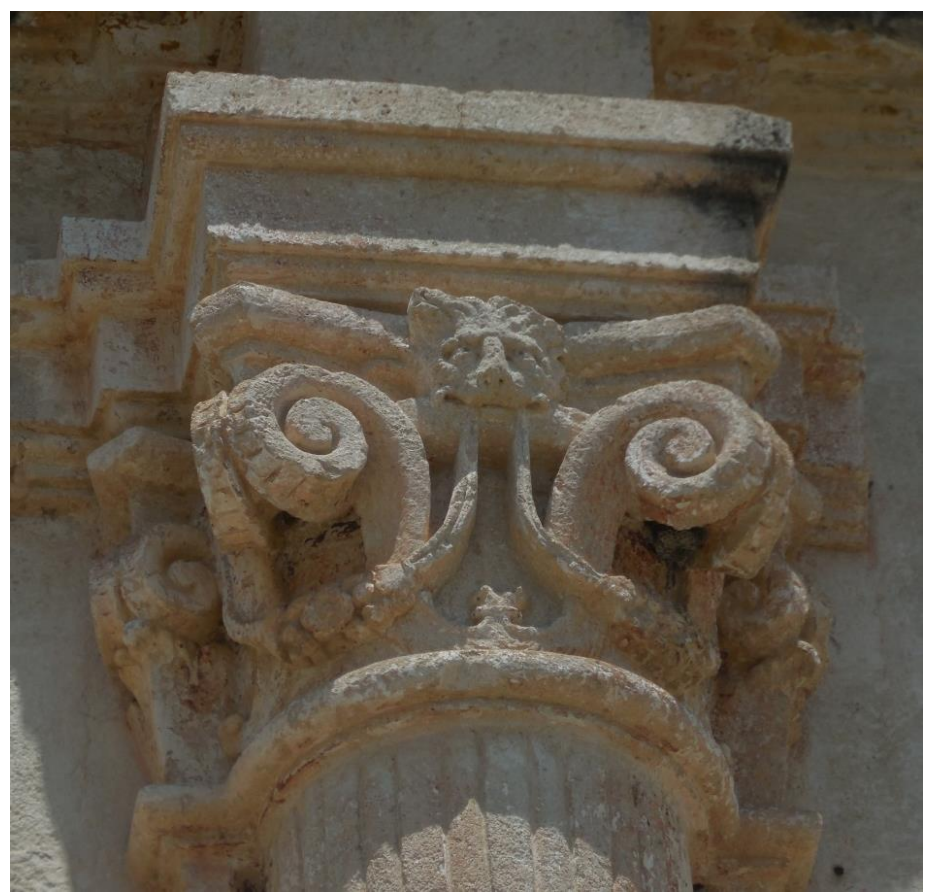

Fig. 4. Cabeza de león en uno de los capiteles de las columnas. Fotografía de Fabiola Moreno Vidal.

\subsection{San Pedro y San Pablo}

A ambos lados de la portada y en medio de los pares de columnas, se ubican las esculturas de san Pedro y san Pablo. Del lado derecho (visto de frente) se ubica san Pablo portando en la mano derecha la espada con que fue decapitado y en la izquierda un libro. Del lado izquierdo está san Pedro portando en la mano derecha un libro, posiblemente en la otra llevaba llaves pero esta parte se ha perdido. Las dos esculturas están apoyadas sobre peanas sostenidas por cabezas de querubines y cubiertas por doseletes, del que cubría a san Pedro solo quedan restos.

Ambos fueron apóstoles, seguidores de Jesús, que dieron su vida por el cristianismo. Están considerados santos fundamentales en la difusión de la doctrina católica en los inicios del cristianismo dentro del Imperio Romano. Se los llamó las dos columnas del edificio de la fe cristiana, por lo que se los representa a ambos lados de la puerta principal y junto a las columnas de los templos, como sostenes y custodios.

En la portada de Metztitlán ambos santos aparecen portando libros, esto puede deberse a que únicamente la vida de estos apóstoles, como divulgadores del cristianismo, está relatada en el quinto libro del Nuevo Testamento, llamado Hechos de los Apóstoles. Esta historia teológica conocida también como Periodo Apostólico engloba los primeros 30 años de la marcha de las primitivas comunidades cristianas. 
Se extiende desde la desaparición de Jesús hasta la llegada de Pablo de Tarso a Roma $^{32}$. La fiesta doble de san Pedro y san Pablo se conmemora el 29 de Junio ${ }^{33}$.
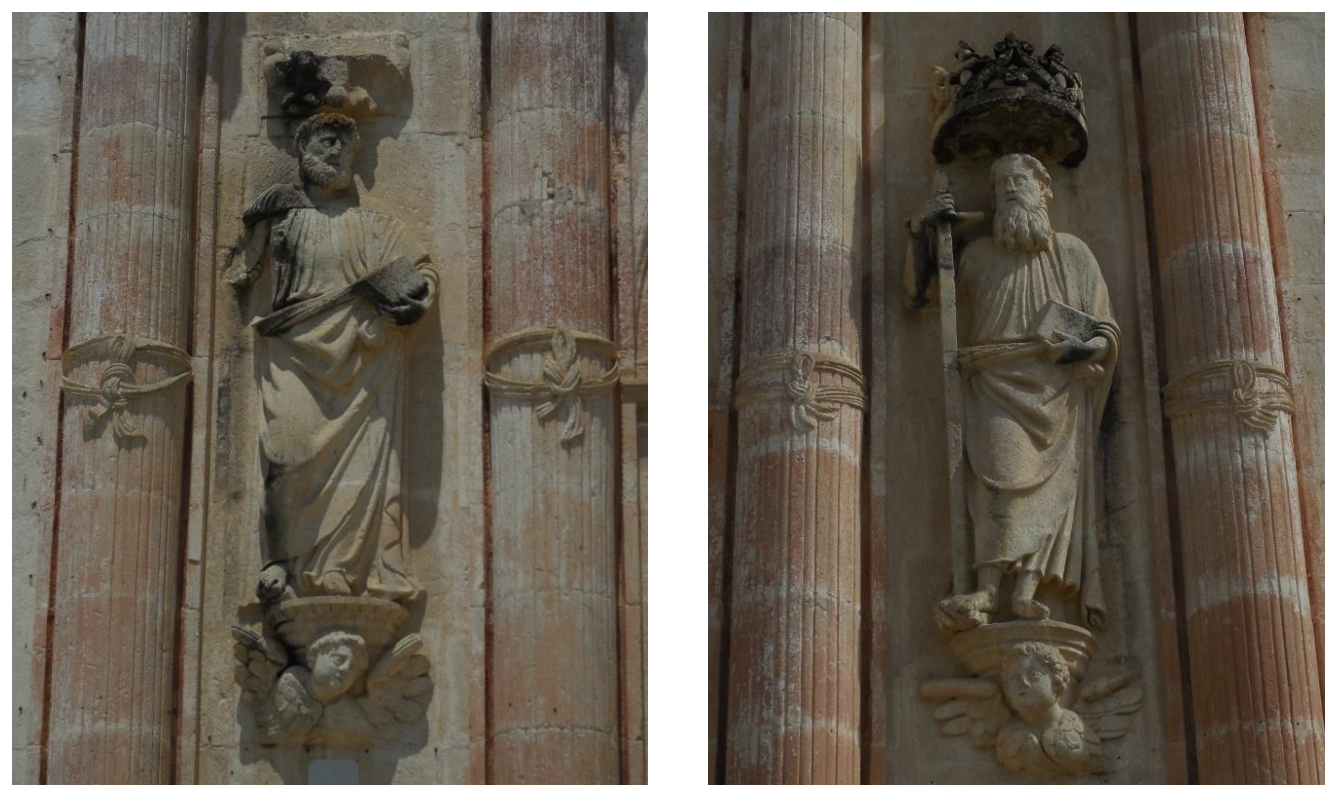

Figs. 5 y 6. Esculturas de san Pedro y san Pablo, ubicadas a ambos lados del arco del vano de ingreso al templo. Fotografía de Fabiola Moreno Vidal.

\subsubsection{San Pedro}

Pescador de Galilea y hermano de Andrés. Aparece en varios episodios de la vida, pasión y muerte de Jesús. Por su seguimiento de Jesús de Nazaret, se constituyó en el apóstol más conocido y citado del Nuevo Testamento en general y de los cuatro Evangelios canónicos y los Hechos de los Apóstoles en particular, que lo presentan bajo muy variados aspectos. Figura de primer orden y de firme valor teológico en razón del ministerio que le confió el propio Jesucristo, es también conocido como el príncipe de los apóstoles. La iglesia católica lo identifica a través de la sucesión apostólica como el primer papa, basándose, entre otros argumentos, en las palabras que le dirigió Jesús: «Tú eres Pedro, y sobre esta piedra edificaré mi Iglesia, y el poder de la muerte no prevalecerá contra ella. Yo te daré las llaves del Reino de los Cielos. Todo lo que ates en la tierra, quedará atado en el cielo, y todo lo que desates en la tierra, quedará desatado en el cielo» (Mateo 16:18-19) ${ }^{34}$.

32 Tu fe católica. (2011). Iconografía de los apóstoles. Las imágenes de los doce apóstoles. [En línea]. Colombia: Los Apóstoles. Disponible en:[ http//. tufecatolica.com] consultado el 24 de enero de 2018

33 Vallés, Tere. (2018). Pedro y Pablo, Santos. [En línea]. España: Solemnidad Litúrgica. Disponible en:[http://es.catholic.net/op/articulos/32203/pedro-y-pablo-santos.html] consultado el 24 de enero de 2018

34 Cabral Pérez, Ignacio. Los símbolos cristianos, Ed. Trillas. México, 1995, p. 289 
A partir del siglo IV a Pedro se lo representa macizo, con rasgos rudos, llevando barba corta y tupida y el pelo ensortijado y con la túnica típica de los apóstoles. Lleva unas llaves en la mano (una de oro y otra de plata), pues son las llaves del cielo y de la tierra, que le da Cristo. Fue crucificado en Roma y pidió que la cruz fuera puesta de cabeza, para no morir como el Señor, pues no se sentía digno de ello. Puede llevar una maqueta de iglesia, un gallo o una cruz de martirio, el báculo que se le atribuye como pastor, y también el pez, símbolo de la promesa de Jesús de Nazaret de hacerlo «pescador de hombres». En el caso de Metztitlán se lo representa portando un libro, seguramente con la otra mano sostenía las llaves, pero el brazo junto con el dosel de la escultura se han perdido ${ }^{35}$.

\subsubsection{San Pablo}

Apóstol, aunque no uno de los doce, personaje muy importante para la historia de la iglesia, pues a él se le debe una gran divulgación de la palabra de Cristo en muchos lugares del imperio romano. Su nombre era Saulo, pero lo cambio a Paulo. En un principio era un enemigo encarnizado de los cristianos, a los que perseguía sin descanso. Pero a partir de una visión se convierte al cristianismo y se dedica predicar, constituyéndose en el motor de construcción y expansión del cristianismo en el Imperio romano, merced a su talento, a su convicción y a su carácter indiscutiblemente misionero. Partidario, por su educación griega, de la tendencia cristiana helenista frente a la judía representada por Pedro y Santiago, será denominado Apóstol de los Gentiles, como consecuencia del Concilio de Jerusalén, hacia el año 48, donde se aprueba la incorporación de los paganos al cristianismo eximiéndoles de la Ley judía (Hch. 15). Este hecho y su consideración como Apóstol de Cristo llevan a representarle en muchas ocasiones emparejado con Pedro, a la derecha o a la izquierda de Cristo entronizado, recibiendo el rollo de la Ley o Evangelio. A través de largos viajes misioneros por el Mediterráneo oriental, funda numerosas comunidades cristianas en Asia Menor, a las que enviará posteriormente diversas cartas apostólicas, que forman el llamado Corpus Paulino, testimonios históricos que hacen de Pablo el principal protagonista y responsable de la introducción del mensaje evangélico en el mundo helenístico ${ }^{36}$. Fue decapitado en Roma bajo el gobierno de nerón.

La iconografía cristiana le representa como a un filósofo de la tradición clásica: calvo, con larga barba y vestido con túnica y manto (siempre después de su conversión, mientras que en las representaciones que atañen a la etapa de persecución del cristianismo aparece vestido como un soldado romano con armadura y capa); suele llevar nimbo como atributo propio de los apóstoles, y más específicamente en el arte cristiano primitivo el libro o rollo relativo a sus cartas epistolares incluidas en el Nuevo Testamento, mientras que hacia el siglo XIII su atributo más común es la espada de su martirio. Al ser considerado Apóstol por la Iglesia, se le representa a la izquierda de Cristo, como cabeza de la Iglesia de los gentiles, por oposición a san 
Pedro situado a la derecha, cabeza de la Iglesia judía, pero hay ocasiones en que este orden se invierte para subrayar el valor de la gentilidad tras el Concilio de Jerusalén o bien como afirmación del poder eclesiástico local frente al de la iglesia de Roma ${ }^{37}$.

\subsection{Pera}

Decorando las jambas del vano de ingreso al templo, se ubican platos con peras, el de la izquierda (visto de frente) es el primer plato que decora la jamba y contiene cinco peras, el de la derecha es el segundo y también contiene cinco, el tercer plato también contiene peras, en este caso tres: la del centro es de mayor tamaño y las dos más pequeñas, se encuentran en posición invertida. (Ver tres), (Ver cinco)
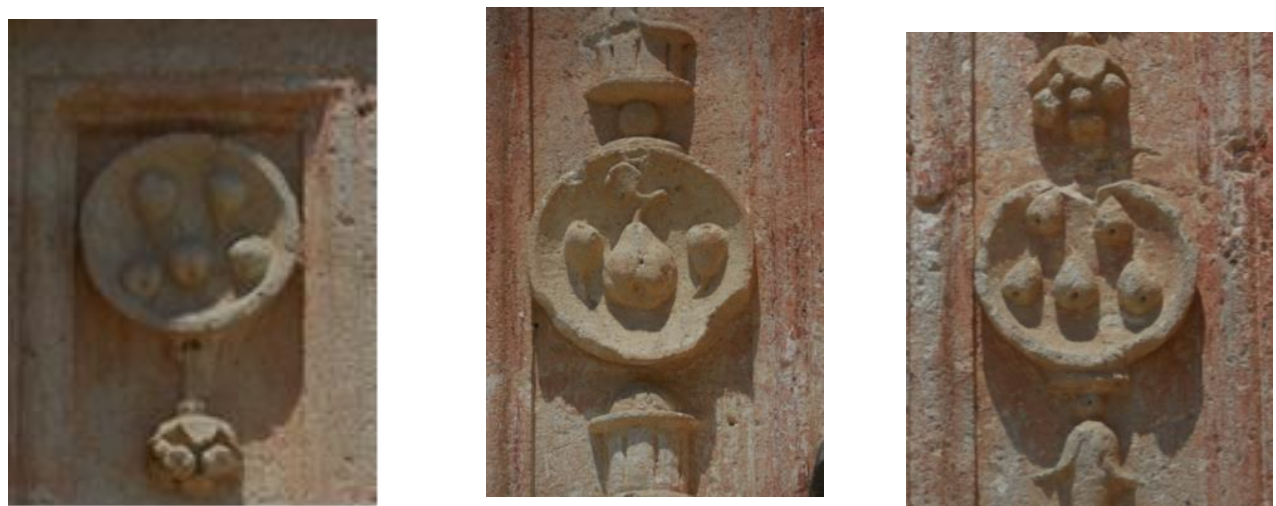

Figs. 7, 8 y 9. Platos con peras, esculpidos en las jambas del vano de ingreso al templo.

Fotografía de Fabiola Moreno Vidal.

La representación de esta fruta está inspirada en uno de los capítulos más famosos del libro Confesiones ${ }^{38}$ escrito por san Agustín de Hipona, en el cual relata un pecado de su adolescencia, (el robo de peras de la huerta de un vecino). A lo largo de este pasaje se cuestiona, el placer que experimentó al hacer el mal por pura satisfacción y surge el desconcierto de por qué realizó este acto, ya que no fue la necesidad ni la escasez de alimentos lo que lo motivó sino el gusto de realizar lo prohibido ${ }^{39}$. Este llegó a ser un tema recurrente para él cada vez que reflexionaba en su vida:

Había un peral en las inmediaciones de nuestra viña cargado de peras, que ni por el aspecto ni por el sabor tenían nada de tentadoras. A hora intempestiva de la noche pues hasta entonces habíamos estado jugando en las eras, según nuestra mala

\footnotetext{
${ }^{37}$ Ibídem

${ }^{38}$ Confesiones es una serie de trece libros autobiográficos de san Agustín de Hipona escritos entre el 397 y el 398. Todo el libro está escrito como una oración de San Agustín hacia Dios, en la cual el reconoce su pecados y la obra que Dios realizó en su vida convirtiéndolo a la fe católica. Es ampliamente aceptada como la primera autobiografía occidental jamás escrita, y se convirtió en un modelo para otros autores cristianos de los siguientes siglos.

39 El Nuevo Ágora. (2008). Las Confesiones de San Agustín, [En línea]. México: Disponible en:[http://elnuevoagora.blogspot.mx/2008/05/las-confesiones-de-san-agustn.html] consultado el 10 de agosto de 2017
} 
costumbre - nos encaminamos a él, con ánimo de sacudirlo y vendimiarlo, unos cuantos mozalbetes. Y llevamos de él grandes cargas, no para regalarnos, sino más bien para tener que echárselas a los puercos, aunque algunas comimos, siendo nuestro deleite hacer aquello que nos placía por el hecho mismo de que nos estaba prohibido ${ }^{40}$.

\subsection{Durazno}

El segundo plato que decora, contando en forma descendente, la jamba izquierda, y el primer plato en la jamba derecha, contienen cuatro duraznos o melocotones cada uno.

El durazno o melocotón (Prunus persica) es originario de China donde existen referencias al cultivo que se remontan a 3000 años. Posteriormente y a través de las rutas comerciales fue introducido en Persia de donde proviene su nombre de clasificación (persicae). Es por esta razón por la que mucha gente cree equivocadamente que el lugar de origen del melocotón es Persia. Los melocotones llegaron a Grecia hacia el año 330 a.C. y durante la Edad Media se extendieron por Europa. En cuanto a la extensión de este cultivo en América, los portugueses introdujeron el melocotón en la costa este de América del sur, y los españoles en Florida y México.

Fueron los exploradores españoles y portugueses los que trajeron el durazno al Nuevo Mundo en el siglo XVI, Gonzalo Fernández de Oviedo, en su "Historia General y Natural de las Indias", indica que trajo de Toledo, España, huesos de durazno, a la Isla Española, hoy conocida como República Dominicana, durante el año 1600 fue introducida al continente y particularmente a México, por lo que es poco probable que los talladores de la portada de Metztitlán conocieran la fruta físicamente ${ }^{41}$.

El melocotón pertenece a la familia de las rosaceas. Es un fruto redondo, rodeado de una cascara muy suave, fina, vellosa y fácilmente pelable. Su pulpa es de un color entre amarillento y blanquecino, dulce, jugosa y desprende un agradable aroma.

Los melocotones pertenecen a la especie de los frutos constituidos de tres partes, o sea, del fruto propiamente dicho, del hueso y del interior de este que encierra la semilla: razón por la que se asociaron a la imagen de la santísima Trinidad. A veces en las representaciones del niño Jesús, este aparece sosteniendo un melocotón, como símbolo de salvación. El origen de semejante interpretación se remonta a una antigua leyenda, según la cual durante la huida a Egipto, un melocotonero se habría doblado en presencia de Jesús ${ }^{42}$.

40 HIPONA, Agustín de. (2007). Confesiones, Libro II. Adolescencia ociosa y culpable en Tagaste, a los dieciséis años (369-370) [En línea]. España: Editorial Libros en Red, 2007. Disponible en: [http://www.iesdi.org/universidadvirtual/Biblioteca_Virtual/Confesiones\%20de\%20San\%20Agus tin.pdf] consultado el 16 de agosto de 2017, pág. 26.

41 Abriendo Surcos, El Durazno Mexicano, un mercado por explorar, Revista mensual producida y editada por Apoyos y Servicios a la Comercialización Agropecuaria, Órgano Desconcentrado de la Secretaría de Agricultura, Ganadería y Desarrollo Rural. Talleres Gráficos de México, N 88, 2000, p. 3- 4

42 Urquiza Ruiz, Teodoro, Símbolos en el arte cristiano, Breve diccionario ilustrado, Ed. Sembrar, España, 2012, p.183 
Debido a que su forma asemeja un corazón y sus hojas, unas largas lenguas, los egipcios lo consideraron como símbolo de veracidad, este significado fue utilizado durante el renacimiento aludiendo a la lengua que habla desde el corazón ${ }^{43}$.
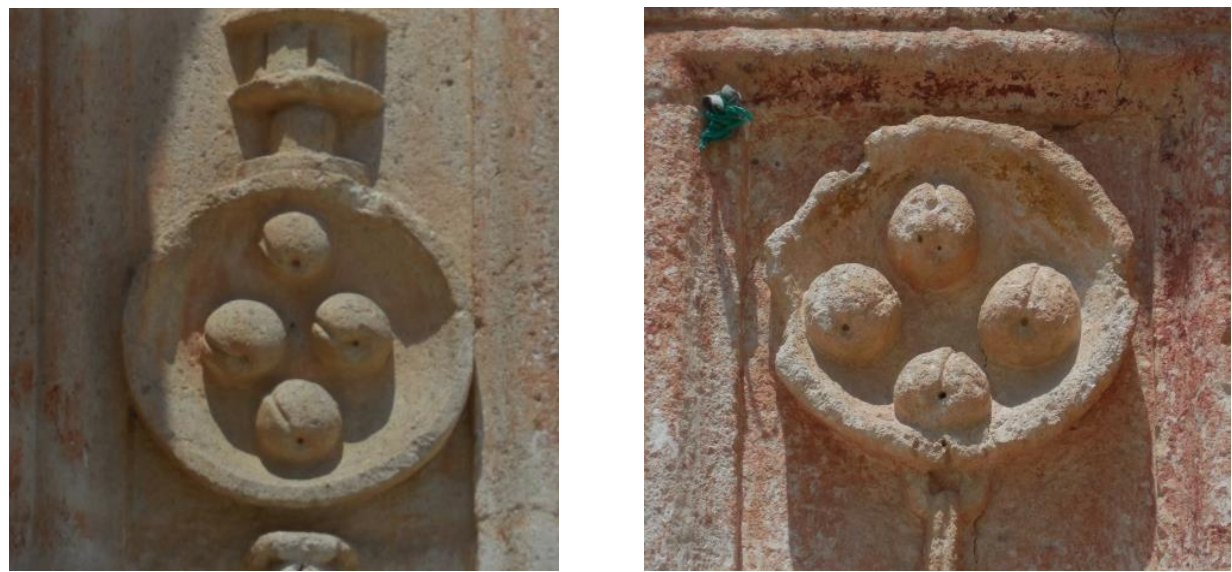

Figs. 10 y 11. Platos con duraznos, esculpidos en las jambas del vano de ingreso al templo. Fotografía de Fabiola Moreno Vidal

\subsection{Granada}

El tercer plato que decora la jamba izquierda, viéndolo de arriba hacia abajo, contiene una granada, es la única en toda la portada, y destaca por su ubicación y gran tamaño.

La granada (Punica granatum), es el único género en la familia Punicaceae y tiene solamente dos especies ${ }^{44}$. El granado es un árbol pequeño de hoja caduca, la fruta crece de una flor roja y puede alcanzar tamaños entre un pomelo y un limón, las membranas interiores de la granada son las que protegen los cientos de granos rojos que la granada contiene $e^{45}$,

La granada cuenta con una rica y larga historia, se cree que su origen es Oriente y las regiones mediterráneas, es decir Persia, Irán y el Himalaya Occidental,.ya que se ha podido rastrear su existencia gracias a documentos históricos fechados en el año 4000 A.c., la granada fue tan bien valorada por los Faraones del antiguo Egipto que es fácil de encontrar representaciones de esta en paredes y tumbas para de esta forma simbolizar la vida después de la muerte, ha sido mencionada desde la antigüedad en libros como El Corán, el libro de Éxodo en la Torá, la homérica Himnos y en registros mesopotámicos, por nombrar algunos ${ }^{46}$.

\footnotetext{
43 Tresidder, Jack, Diccionario de los símbolos, Ed- tomo, México, 1999, p. 86

44 Visitarb Madrid. (2017). Simbología de la Granada [En línea]. España: Recorridos botánicos por los jardines y espacios verdes de Madrid. Disponible en:[http://www.visitarb.com/simbologia-lagranada/] consultado el 10 de agosto de 2017

Campo de elche. (2017). Historia de la Granada fruta. [En línea]. España. Disponible en:

[https://campodeelche.com/historia-de-la-granada-fruta-salud-en-cada-grano/] consultado el $10 \mathrm{de}$ agosto de 2017

Ibídem
} 
El nombre botánico Punica se deriva del latín punicus, que significa escarlata o rojo, pero también se refiere a las llamadas guerras púnicas. Un nombre temprano fue Malum punicum (manzana de Cartago). Habiendo sido traído de Cartago por los soldados romanos, fue introducido más adelante en Europa meridional y España. Una pequeña rama con una granada abierta está en el escudo de armas de Granada, y la provincia tomó realmente su nombre de la fruta. El nombre específico granatum fue dado debido a las muchas semillas duras ${ }^{47}$. La palabra granada, "rimon" en hebreo, se deriva de las palabras latinas "pomum" (manzana) y "granatus" (semillas). Crecida en la región del Mediterráneo durante varios miles de años.

La granada, en el mundo clásico fue atributo de Proserpina (Persefone), quien después de comerse unos granos fue condenada a permanecer en el Hades durante 6 meses por tanto la fruta simboliza la desolación del otoño y el invierno así como la regeneración de la primavera y el verano.

La palabra hebrea para la granada es rimmon, y muchas referencias que la contienen se encuentran en el Antiguo Testamento. La granada es uno de los frutos que la tierra prometida produce en abundancia, garantizando la vida: la tierra dada por Dios es rica porque es "tierra de trigo, de cebada, de vides, de higos y de granadas; tierra de olivos, de aceite y de miel" (Dt 8:8) ${ }^{48}$.

Esas fueron las riquezas que Moisés prometió a su pueblo cuando las sacó de Egipto a la tierra prometida ${ }^{49}$.

Esta fruta notable es rica en simbolismo y hay referencias especificas a esta fruta en la biblia ${ }^{50}$ : El libro de los Reyes 7:13-22, al referirse a la edificación de las columnas del pórtico del templo de salomón, construido por Hiram, destaca en el versículo 18: "y cuando hubo hecho las columnas, hizo también dos órdenes de granadas, alrededor una enredada para cubrir los capiteles que estaban en las cabezas de las columnas con granadas; y de la misma forma hizo el otro capitel"51. El rey Salomón se dice que ha diseñado su corona sobre la base de la "corona" de esta fruta $^{52}$.

La granada, por sus numerosas semillas, siempre ha sido un signo de abundancia, riqueza, fertilidad, vida eterna y realeza, al estar rematado por un cáliz en forma de corona. Para el cristianismo, La forma esférica, la abundancia de los granos y el agradable olor significaron la perfección, el infinito número de atributos y (la bondad) las múltiples bendiciones de Dios.

Visitarb Madrid. op.cit.

Gelsomino del Guercio. (2016). ¿Qué significa la granada en la Biblia?. [En línea]. Italia: Aleteia. Disponible en: [https://es.aleteia.org/2016/10/14/que-significa-la-granada-en-la-biblia/2/] consultado el 10 de agosto de 2017

$49 \quad$ Visitarb Madrid. op.cit.

50 Sanando La Tierra. (2016). Pomegranate - Simbolismo De La Granada En La Biblia - Beneficios Para La Salud - Presión - Colesterol [En línea]. USA. Disponible en:

[https://www.sanandolatierra.org/pomegranate-simbolismo-de-la-granada-en-la-biblia-beneficiospara-la-salud-presion-colesterol/] consultado el 10 de agosto de 2017

51 Gadea Saguier, Christian. (2006). La granada, fruto de la armonía [En línea]. Paraguay: blog Los Arquitectos. Disponible en:[http://losarquitectos.blogspot.mx/2006/04/la-granada-fruto-de-laarmona.html] consultado el 10 de agosto de 2017

52 
La granada simboliza la unidad de la comunidad cristiana, por tener semillas numerosas, pero que permanecen juntas dentro de una misma piel y bajo una misma autoridad. El zumo rojo recordaba la sangre de los mártires, la piel dura e incomestible, pero que guarda en su interior un zumo dulce, simbolizó en ocasiones la perfección del cristiano y especialmente la del sacerdote.

En la mística cristiana, este simbolismo se enriquece de significado espiritual hasta considerar el fruto y sus semillas expresión de la resurrección de Cristo y de la perfección divina, esto a partir de la Edad media. Un único fruto que reúne tantas semillas preciosas representando la unión misma de la Iglesia Este significado es el que se quiere ilustrar en la portada de Metztitlán, la unión que debe existir entre los frailes agustinos y su labor evangelizadora.

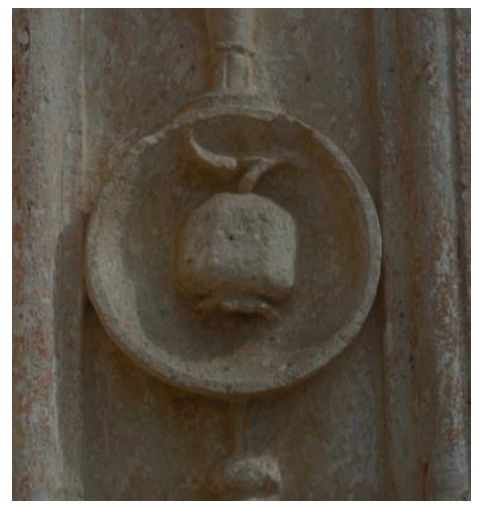

Fig. 12. Plato con granada, esculpida en la jamba izquierda (vista de frente) del vano de ingreso al templo. Fotografía de Fabiola Moreno Vidal.

\subsection{Pez}

Decorando la portada en la base de las jambas y a ambos lados del vano de ingreso al templo, se encuentran esculpidos dos platos con tres peces cada uno.

Hace aproximadamente unos dos mil años antes de la era cristiana, en las primeras civilizaciones de Europa y Asia, el pez fue considerado como emblema de fecundidad humana y animal. Esto debido a la gran cantidad de huevas que lleva dentro de sí y por la creencia de los antiguos pueblos que situaba en las aguas profundas el punto de partida de la vida en el mundo.

En las regiones más septentrionales de Europa, el espíritu de las aguas, que primero había sido concebido en forma de pez, se fue revistiendo poco a poco de todas las facultades intelectuales del hombre y se convirtió en el ser hibrido mitad pez, mitad hombre; se lo conoció entonces con el nombre de Oanes, al norte y al este del Éufrates, y Dagón al oeste y al sur de este rio, cada uno fue considerado como el señor de la tierra y de las vidas que alimenta, y como mediador, también, entre el cielo y la tierra $^{53}$.

53 Charbonneau-Lassay, L., op.cit. Vol. II, p. 688. 
Se relaciona entonces, en ciertos aspectos con el Logos de los griegos, es decir con el principio divino que crea, domina y dirige la Naturaleza y el Universo entero.

Al fundarse la iglesia cristiana, los propios apóstoles, en sus primeros discursos, aplicaron ya a Jesús todos los pasajes importantes de las escrituras sagradas de Israel que podían adecuarse a su calidad de doctor y redentor y sobre todo a su doble naturaleza divina y humana.; por eso en su Epístola a los Efesios, san Pablo, compara la unión natural y santificada del hombre y la mujer, con la unión espiritual de Cristo con su iglesia, que a su vez se relaciona con las palabras bíblicas: "Creced, multiplicaos y llenad la tierra". Partiendo de ahí, es comprensible que los primeros cristianos apliquen al Cristo divino el antiguo emblema de todas las fecundidades como es el pez.

La particularidad, en la que está ausente la copula carnal, al realizar la fecundación directa por parte del pez macho de los huevos puestos por la hembra, era una razón más en favor del pez y su aplicación, no solo a la unión del Salvador y de su Iglesia, sino también, en cierta forma, al misterio de su propio nacimiento en la vida terrena.

Por otra parte, los viejos mitos caldeo asirios de Oanes o Dagón, bien pudieron no ser totalmente ajenos a la adopción, por parte de los primeros cristianos, del pez como símbolo del Salvador del Mundo.

Se cree que un cristiano, un griego de alejandria, se dio cuenta de que tomando por inicial de uan palabra cada una de las letras de la palabra griega ICQC, ictus, se puede obtener la siguiente frase:

\begin{tabular}{|c|c|c|}
\hline YC & XPICTOC & QHON \\
\hline
\end{tabular}

Este acróstico tuvo gran éxito sobretodo en Roma, y de allí se difundió ya sea como el pez o su nombre por todos los lugares donde el cristianismo se había establecido para que sus practicantes se pudieran identificar en secreto. Este era a la vez un reconocimiento de Jesús como salvador y una protesta contra la reprobación que le manifestó el sumo sacerdote de los judíos cuando, durante su pasión, Jesús proclamó ser el verdadero Hijo de Dios.

Durante la edad media se conserva un emblema muy antiguo del pez, que tienen que ver con Jesucristo, son tres peces absolutamente parecidos entre sí, unidos por una sola cabeza central, confiriendo al Padre y al espíritu Santo la apariencia de peces, forma que en realidad solo identifica al Hijo.

Posiblemente fue este significado, entre otros, el que se quiso representar en la portada de Metztitlán, al colocar tres peces de similares características entre sí, pero uno junto a otro, que representan a la Santísima Trinidad.

Los primeros cristianos, también, se designaban a sí mismos como "hijos del Ictus celestial", el "Gran Pez", el "Pez Divino", al que debían seguir e imitar en todo, según el pasaje del siglo II de Tertuliano (De baptismo, c. 1): "Nosotros, pececillos conforme a nuestro Pez, Jesucristo, nacemos en el agua (bautismal) y no podemos salvarnos más que si permanecemos en el agua", o sea en la fe del bautismo. El cristiano que se aparte de la gracia del Espíritu Santo muere. Como el pez muere al salir del agua ${ }^{54}$.

54 http://www.corazones.org. (2017). El pez, símbolo cristiano [En línea]. España. Disponible en: [http://es.catholic.net/op/articulos/53274/cat/66/el-pez-simbolo-cristiano.html] consultado el 5 de septiembre de 2017 
Dentro del simbolismo empleado por los primeros cristianos la figura del pez eucarístico de forma velada, representa a Cristo sacrificado. A consecuencia de este significado eucarístico, los primeros artistas cristianos representaron al pez entre las especies materiales de la Eucaristía, sobre un plato entre la copa y el pan y entre otros objetos referentes al banquete sacramental. Cuando el cristianismo, tras el edicto de 314, se convirtió en la religión oficial, las decoraciones de las primeras basílicas repitieron estas composiciones sin cambiar su significado, las mismas, servirían de inspiración a los artistas de la edad media.

La presencia del pez simbólico es muy probablemente una alusión a aquella cena que Jesús tras su resurrección, hizo compartir a siete discípulos suyos que pescaban a la orilla del lago Tiberíadaes. Cuando se le acercaron, dice san Juan (evangelio XXI, 9), vieron carbones encendidos sobre la arena de la orilla, un pescado puesto encima y un pan al lado. Y Jesús les dijo: "Venid y comed", y tomando el pan, les dio de él; y lo mismo hizo con el pescado.

Parece seguro que este relato evangélico contribuyó mucho a darle al pez simbólico su significado eucarístico, pues este episodio de los siete discípulos favorecidos fue el predilecto en la composición de lso banquetes misticos en el arte cristiano primitivo.

Más aún, S. Agustín explica: "Místicamente, es el pez asado figura de Cristo crucificado; El mismo es el pan que bajó del cielo. A éste está incorporada la Iglesia para participar de la bienaventuranza eterna." (in Ioannem, tract., 123, en "Catena Aurea" de Sto. Tomás de Aquino) ${ }^{55}$.

Este es otro de los significados que le se les otorga a los peces de la portada de Metztitlán, son el cuerpo de Cristo del que se alimentará el hombre en el gran banquete eucarístico, tras su conversión al cristianismo por medio del bautismo.
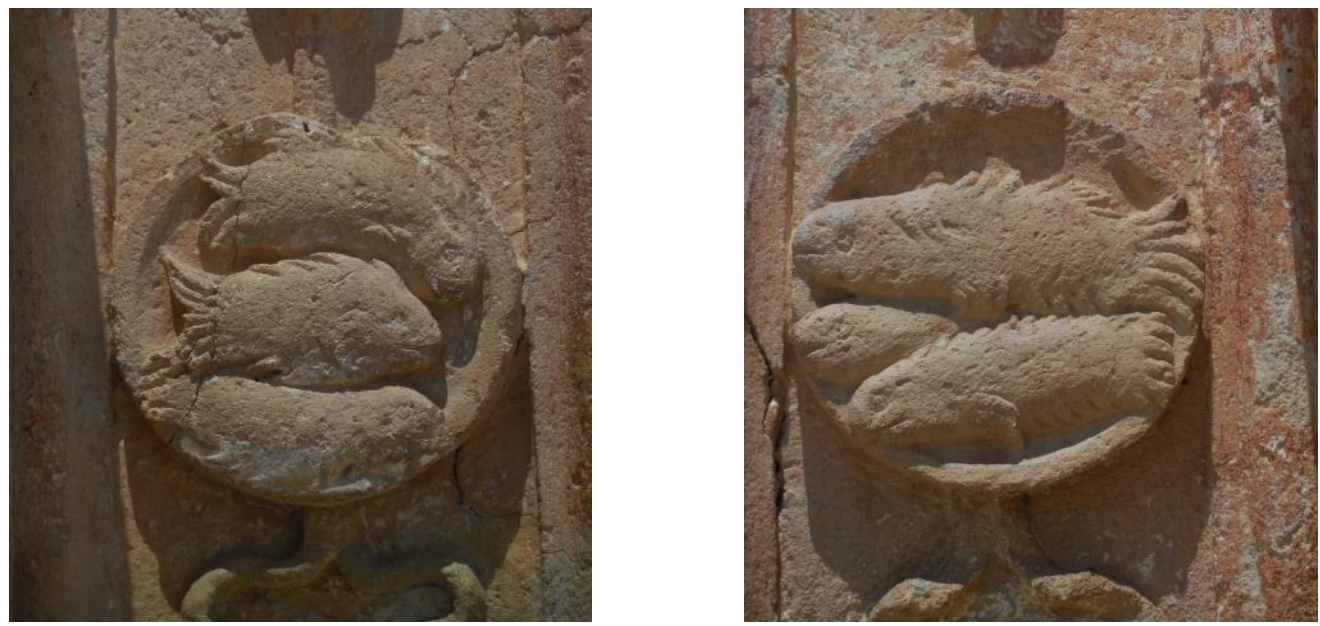

Figs. 13 y 14. Platos con peces, esculpidos en las jambas del vano de ingreso al templo.

Fotografía de Fabiola Moreno Vidal.

55 Lourdes, María. (2010). ¿Por qué es el pez un símbolo cristiano? [En línea]. España. Disponible en: [http://infocatolica.com/blog/sarmientos.php/1004231158-ipor-que-es-el-pez-un-simbolo] consultado el 5 de septiembre de 2017 


\subsection{Flores}

En las culturas antiguas de occidente, los astros estilizados en forma floral eran algo más que mera decoración para llenar espacios; más bien eran expresión de una imagen del mundo que sabía de las conexiones entre la vegetación, dependiente del ciclo anual, y los movimientos de los astros ${ }^{56}$.

El cristianismo asimiló estos significados y los incluyó en la decoración de sus templos, como por ejemplo en los rosetones, donde los elementos vegetales y astrales se fusionan, con el paso del tiempo ambos se han influido mutuamente, mezclándose.

El trasfondo histórico y espiritual, que explica la acogida de las flores y hierbas en el arte de finales de la edad media, hay que buscarlo en la imagen simbólica del mundo que prevalecía en esa época; en esa imagen todas las cosas terrestres y los acontecimientos todos se interpretaban como una prefiguración (prefiguratio) y semejanza (similitudo) de lo divino ${ }^{57}$.
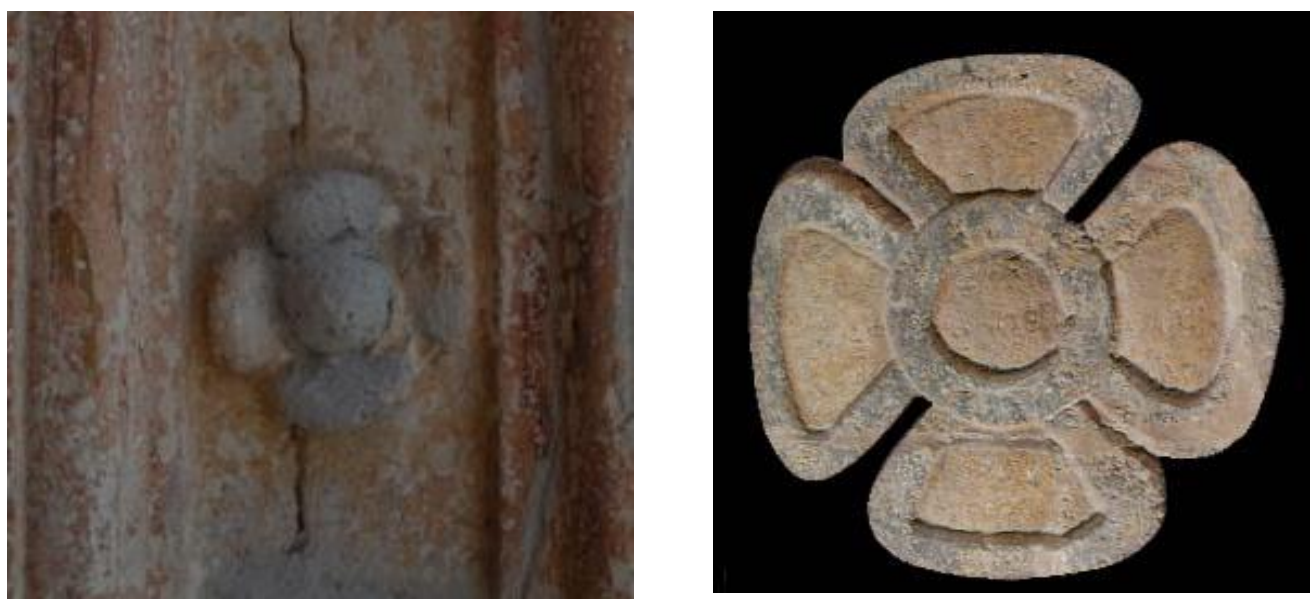

Fig. 15. Flor de cuatro pétalos, ubicada en diferentes partes de la portada, representación del Nahui-Ōlin para los indígenas. Fotografía de Fabiola Moreno Vidal.

Fig. 16. Flor teotihuacana, imagen muy representada en el mundo mesoamericano y que para la cultura náhuatl expresó su visión del cosmos. Tomado de

http://abakmatematicamaya.blogspot.mx/2011/11/bak-matematica-maya-quincunce-en.html

\subsubsection{Nahui-Ōlin}

Las imágenes de flores que están presentes en la portada, es decir, las que se encuentran en las jambas y el intradós del arco y las que enmarcan al Niño Salvador del Mundo, están expresadas como flores de cuatro pétalos con núcleos circulares,

\footnotetext{
56 Lurker, Mamfred, El Mensaje de los Símbolos, mitos, culturas y religiones, Barcelona, Herder, 2000, p. 183

$57 \quad$ Ibídem
} 
estas son representaciones del Nahui-Ōlin, o flor solar, concepción del universo, del tiempo y del espacio de la cultura náhuatl.

Nahui-Ōlin significa cuatro-movimiento en náhuatl. Representa al quinto sol, de acuerdo a la mitología náhuatl la tierra ha pasado por cinco etapas diferentes desde su creación, regidas cada una por un sol. Según los mexicas existieron cuatro soles o edades antes que la nuestra, cada una de las cuales finalizó con grandes catástrofes naturales que diezmaron a la humanidad ${ }^{58}$. El Quinto Sol o "Quinta Era" según la cosmogonía de los aztecas concluyó hacia finales del año 2012.

El Nahui-Ōlin es el símbolo que guarda la concepción del Universo, es decir, del Espacio y el Tiempo de la cultura náhuatl. Es la figura omnipresente en la iconografía y fue representado bajo infinitas variantes tanto en códices como el Borbónico y en estelas como la Piedra del Sol, pero siempre formado por 4 puntos unificados por un centro. En la simbología náhuatl el 5 es la cifra del centro, es el eje del que parten los 4 rumbos del Universo y su centro constituye el punto de contacto entre el Cielo y la Tierra $^{59}$. En la portada de Metztitlán, así como en muchas portadas del siglo XVI, el Nahui-Ōlin ha sido representado como una flor de cuatro pétalos con un núcleo bien diferenciado.

El Nahui-Ōlin, se refiere a la conjunción del Sol con el planeta Venus, marca la importancia simbólica de este acontecimiento ${ }^{60}, 5$ ciclos sinódicos venusianos corresponden casi exactamente a 8 años de 365 días $(5$ X 584 días $=8$ X 365 días $=$ 2920 días). La conexión con el "año ritual" de 260 días se daba después de un Huehuetiliztli, período de 104 años que corresponde a 65 ciclos sinódicos venusinos y 146 "años rituales" 61.

El Nahui-Ōlin eje de la filosofía náhuatl refleja la naturaleza física de su creador Quetzalcóatl (el planeta Venus en movimiento). Es un lugar donde espacio y tiempo se unen en uno solo, en el que el ave habita las tres dimensiones del cielo y la serpiente habita las dos dimensiones de la tierra. Es el sol en el centro del cielo, el momento cuando el águila celeste custodiada por los cuatro rumbos, se posa en el cenit $^{62}$. Por las parábolas de Quetzalcóatl, se sabe que es durante el ciclo vital del corazón, cuyo símbolo es también el Nahui-Ōlin, debe alcanzar su florecimiento, es decir, debe llegar a ser un "corazón florido" 6364.

Tribu Arcoíris: "El Quinto Sol: Profecía Azteca y Otras Culturas", 26 de noviembre de 2011; disponible en [http://tribuarcoiris.blogspot.mx/2011/02/quinto-sol-mayas-aztecas-mitos.html] consultado el 20 de enero de 2016 Filo Zitlalxochitzin: "El Nahui-Ollin plasmado en el Calendario Azteca y en la Pintura Guadalupana: el universo de la cultura náhuatl cifrado en un símbolo", Dec 7, 2013; disponible en

[http://www.tonantzinguadalupe.org/el-nahui-ollin-plasmado-en-el-calendario-azteca-y-en-lapintura-guadalupana/] consultado el 4 de agosto de 2015

60 Laurette Séjourné, op. cit., p. 62

61 Esperanza Carrasco Licea \& Alberto Carramiñana Alonso, op. cit.

62 Puri2aprendiendovida, op. cit.

63 Filo Zitlalxochitzin, op. cit.

64 Este apartado se extrajo de la páginas 78 del artículo “Análisis iconográfico de la portada del Templo de San Francisco de Asís en Tepeapulco Hidalgo" publicado por la autora en la revista Eikón Imago No. 12 (2017 / 2) ISSN-e 2254-8718 


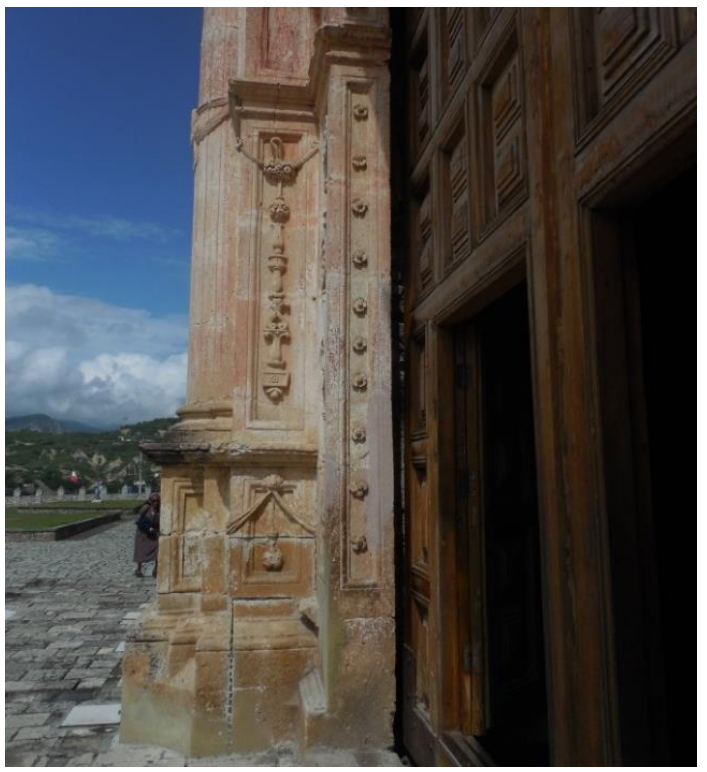

Fig. 17. Hilera de diez flores, ubicadas en la cara interna de las jambas del vano de ingreso al templo. Fotografía de Fabiola Moreno Vidal.

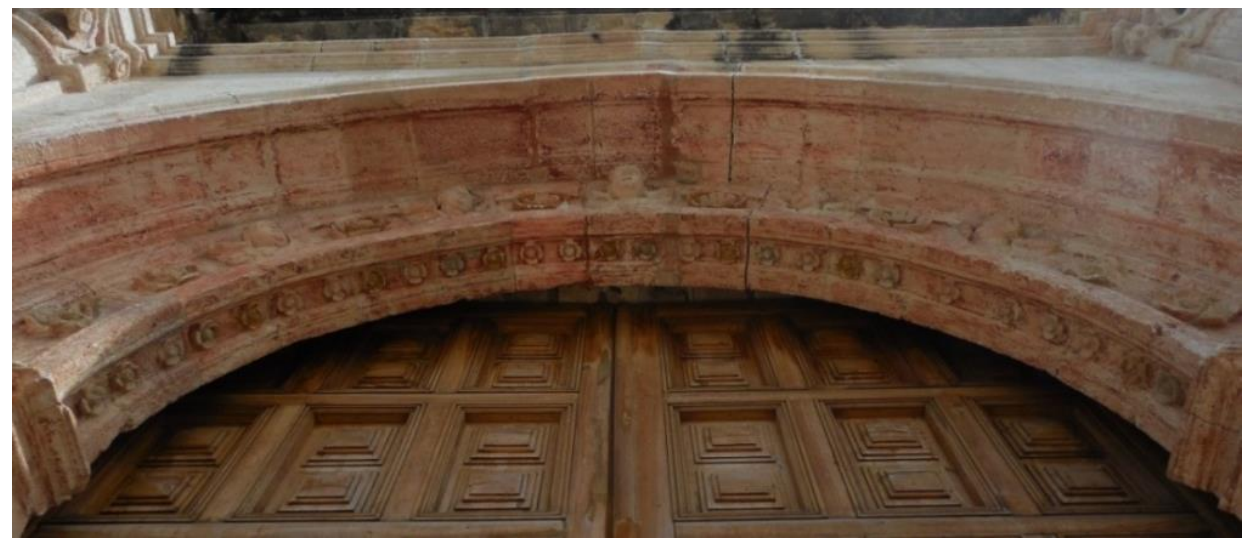

Figs. 18. Intradós del arco del vano de ingreso al templo decorado con veintisiete flores. Fotografía de Fabiola Moreno Vidal.

\subsubsection{Veintisiete}

En el intradós del arco, se ubican 27 flores de cuatro pétalos, algunas conservan restos de pintura en colores rojo, azul y amarillo. El número 27 está relacionado con la posible fecha del bautismo de Jesús e inicio de su ministerio según algunas cronologías cristianas. De acuerdo a lo que dice el evangelio de Lucas (Lc 3:1-2.2123) Jesús tenía unos treinta años cuando fue bautizado por Juan en el año decimoquinto del imperio de Tiberio César que, debió corresponder al 780 ó 781 de 
Roma, 27-28 de la era cristiana,. Este sería el año del bautismo de Cristo y del comienzo de su ministerio ${ }^{65}$.

Cabe mencionar que el Nuevo Testamento está compuesto por 27 libros, El alfabeto hebreo tiene 27 letras, así como el alfabeto español ${ }^{66}$

\subsection{Rosa}

El arco que enmarca el vano de ingreso al templo está decorado con relieves de rosas intercaladas con cabecitas aladas de querubines, las rosas se presentan en número de 8 y los querubines de 5 .

El género Rosa está compuesto por un conocido grupo de arbustos espinosos y floridos representantes principales de la familia de las rosáceas. Se denomina rosa a la flor de los miembros de este género y rosal a la planta ${ }^{67}$.

La palabra rosa viene del latín rosa que está emparentado con el griego

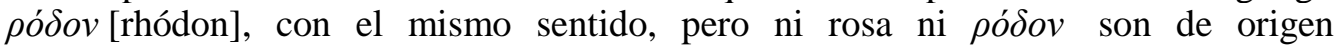
indoeuropeo. En latín y en griego el nombre de esta flor es un préstamo de una antigua lengua mediterránea, posiblemente semítica ${ }^{68}$.

Evidentemente, ya desde la antigüedad, el cultivo de rosales estaba muy difundido, ya sea como plantas ornamentales como también para provecho de sus propiedades medicinales y aromáticas (perfumería y cosmética). Los primeros datos de su utilización ornamental se remontan a Creta (siglo XVII a. C.). La rosa original tenía cinco pétalos ${ }^{69}$.

Su belleza, fragancia y delicadeza han hecho de ella un símbolo de amplia tradición, sobretodo en occidente, donde es la flor sagrada, sus cinco pétalos simbolizan el número sagrado 5 que representa al hombre y el microcosmos, por eso su equivalencia con la estrella de cinco puntas (pentagrama o pentalfa) son los cuatro elementos y la quintaesencia ${ }^{70}$.

Probablemente la rosa, proviene del norte de Persia, del entorno del mar Caspio o del golfo Pérsico, desde donde se extendió, a través de Mesopotamia, a Palestina y Asia Menor. En Egipto y Grecia tuvo una especial relevancia, y mucho más en Roma,

65 José. (2007). Fechas clave de Jesús [En línea]. España: Textos de la historia de la Iglesia. Disponible en: [http://textoshistoriadelaiglesia.blogspot.mx/2007/12/fechas-clave-de-jess.html] consultado el 15 de septiembre de 2017 Morazán. (2016). 27 datos curiosos del número 27 [En línea]. Honduras: centrodeamerica.net Disponible en: [ http://centrodeamerica.net/27-datos-curiosos-del-numero-27/] consultado el 15 de septiembre de 2017 Wikipedia. (2017). Rosa. [En línea].USA. Disponible en: https://es.wikipedia.org/wiki/Rosa consultado el 25 de enero de 2018 Moreno, Juan Carlos. (2016). Etimología de Rosa [En línea]. Chile: Etimologías. Disponible en: [http://etimologias.dechile.net/?rosa] consultado el 25 de enero de 2018 Cerrillo, Antonio. (2010). Culturas antiguas, religiones, creencias e ideologías han utilizado la rosa como emblema [En línea]. España: La Vanguardia Libros. Disponible en: [http://www.lavanguardia.com/libros/20100423/53913545357/culturas-antiguas-religionescreencias-e-ideologias-han-utilizado-la-rosa-como-emblema.html] consultado el 25 de enero de 2018

70 Loyal, Simón. (2012). El Simbolismo de la Rosa. [En línea]. España: Antroponomicon. Disponible en: [https://antroponomicon.wordpress.com/2012/01/05/el-simbolismo-de-la-rosa/] consultado el 25 de enero de 2018 
donde se cultivó intensamente, las rosas rojas se consagraban a Venus y la fiesta de las rosas, era símbolo de la sangre: regeneración, vida y muerte. En primavera las Rosalías, formaban parte de las ceremonias ligadas al culto de los muertos ${ }^{71}$. Durante la Edad Media, su cultivo se restringió solo a los Monasterios.

En primavera el arcángel Gabriel anunció la buena nueva a la Virgen María, y la Palabra de Dios Padre descendió a su seno materno y se hizo carne. La vieja profecía mesiánica del retoño (pimpollo) de la raíz de Jesé pronto se transformó textualmente en "ha brotado una rosa", y así se cantó. En la noche sagrada apareció la flor divina sobre la tierra: el Logos encarnado, hecho carne. Mas todo lo que florece en este mundo está sujeto al cambio. Y de nuevo en primavera, en la fiesta de Pascua, Jesús crucificado se levantó del sepulcro, y de su sangre derramada en abundancia llego la plena floración $^{72}$.

Normalmente la rosa, equivale en su simbolismo al del corazón. El corazón es utilizado por los antiguos como un símbolo del centro espiritual del Ser. Cuando el corazón es llenado por el conocimiento divino, se representa como una rosa de pétalos abiertos. Porque ha florecido en él la actualización de su naturaleza primordial, de su pureza inicial, aquella que perdemos, en la caída hacia el mundo material ${ }^{73}$.

El corazón es la verdadera raíz de la energía vital que opera de continuo, únicamente su sangre posibilita la flor de la que procede el fruto. Esta idea fue representada por los primeros cristianos como un rosal donde se encuentra Cristo crucificado, y donde en el lugar del corazón se encuentra un rosa ${ }^{74}$. San Bernardo vio en la rosa de cinco pétalos las cinco llagas de Cristo. Las rosas rojas son una referencia a su pasión y al cáliz donde se vertió su sangre para redimir a la humanidad, la flor con espinas fue la imagen de tormento de los mártires ya que según la antigua creencia cristiana, los mártires florecen plenamente con la entrega de su sangre ${ }^{75}$. La tradición dice que la rosa crecía en el paraíso y que no tenía espinas, pues estas el salieron debido al pecado de Adán y Eva. La Virgen María es una "rosa sin espinas", pues ella fue concebida sin la falta original. El "rosario" originalmente era una sarta de rosas, de ahí su nombre ${ }^{76}$.

La rosa es símbolo de poderío, de instrucciones espirituales pero también de regeneración, resurrección e inmortalidad. El rosetón gótico y la rosa de los vientos muestran claramente el paso de la simbología de la rosa a la de la rueda. Y es símbolo de éxtasis o de renacimiento místico ${ }^{77}$.

Es en todo caso entre muchas cosas, es un símbolo de regeneración, resurrección y vivificación. Cuando el corazón se abre y florece la rosa, se puede percibir el delicioso aroma del paraíso.

\footnotetext{
$71 \quad$ Cerrillo, Antonio. op.cit.

72 Lurker, Mamfred, op.cit., p. 188

73 Loyal, Simón. op.cit.

74 Cerrillo, Antonio. op.cit.

75 Lurker, Mamfred, op.cit., p. 188

76 Cabral Pérez, Ignacio. op.cit., p. 115

77 Cerrillo, Antonio. op.cit.
} 


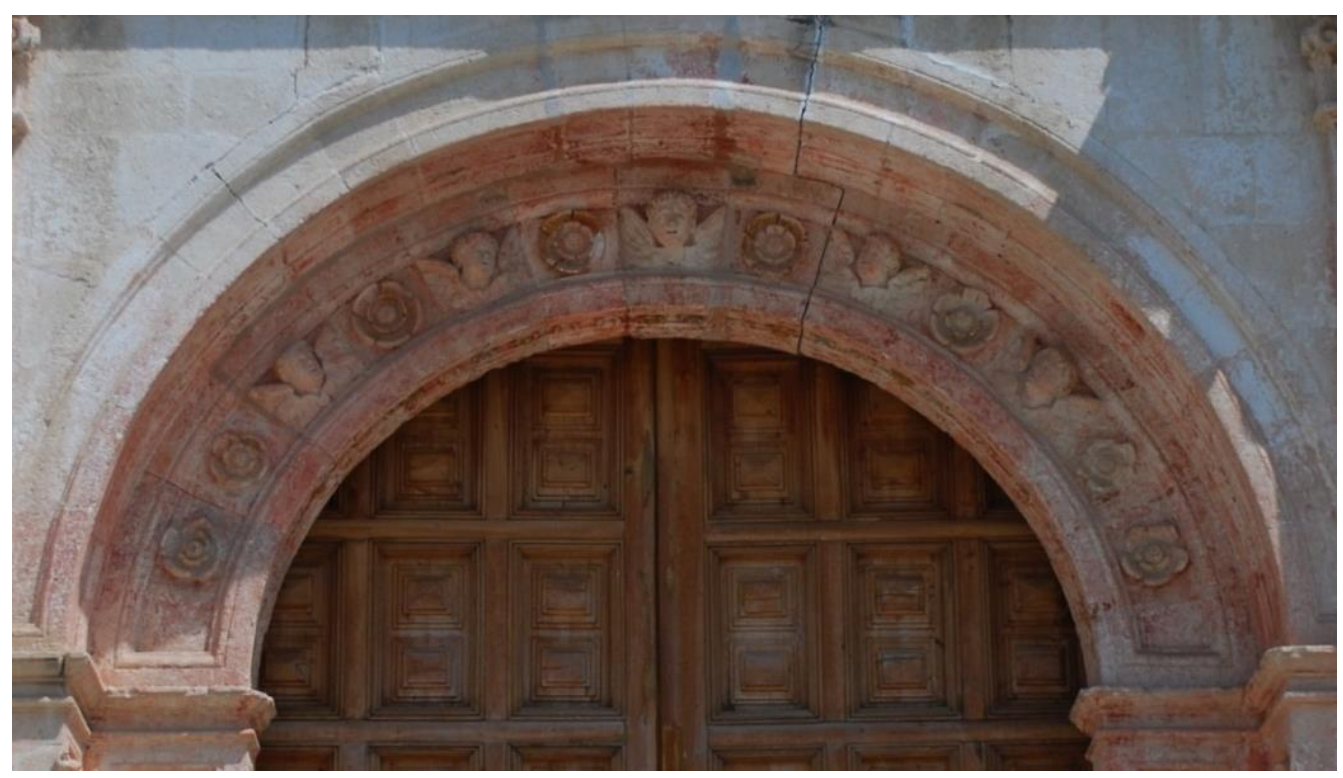

Fig. 19. Arco de ingreso al templo decorado con ocho rosas y cinco querubines.

Fotografía de Fabiola Moreno Vidal.

\subsection{Querubines}

En la angelología cristiana, un querubín es un tipo de ángel, el segundo de los nueve coros angélicos. La palabra cherub (cherubim es el plural masculino en hebreo) es una palabra tomada del asirio kirubu, de karâb, "estar cerca", por lo que significa los que están cerca, familiares, sirvientes personales, el cuerpo de guardias, cortesanos. Se usa comúnmente para designar a los espíritus celestiales que rodean cercanamente la Majestad de Dios ${ }^{78}$.

Se les suele representar con la forma de un niño con alas, o solamente la cabeza con alas ${ }^{79}$. Por su característica de guardianes se los representa muy cerca de las puertas de ingreso a los templos. Cumplen la función de vigías del atrio, es decir de la viña del Señor y a su vez protegen la entrada al templo donde habita Dios. En la portada de Metztitlan las cabecitas aladas de querubines se hallan decorando el arco que flanquea el vano de ingreso al templo y las peanas de san Pedro y san Pablo que se ubican a los lados de la puerta.

Por lo tanto, la decoración con ocho rosas y cinco querubines, aluden al sacrificio del hijo de Dios con sus llagas y al mismo tiempo a su resurrección y es una invitación al cristiano que siga ese mismo camino, transmutando la muerte terrenal a través del bautismo hacia la vida eterna.

\footnotetext{
78 Arendzen, John. (2005). “Cherubim”. Fuente: The Catholic Encyclopedia. Vol. 3. [En línea]. USA: Ecwiki encyclopedia católica on line. Disponible en:

79 [http://ec.aciprensa.com/wiki/Querub\%C3\%ADn] consultado el 25 de enero de 2018

Beker, Udo, op.cit., p. 351
} 


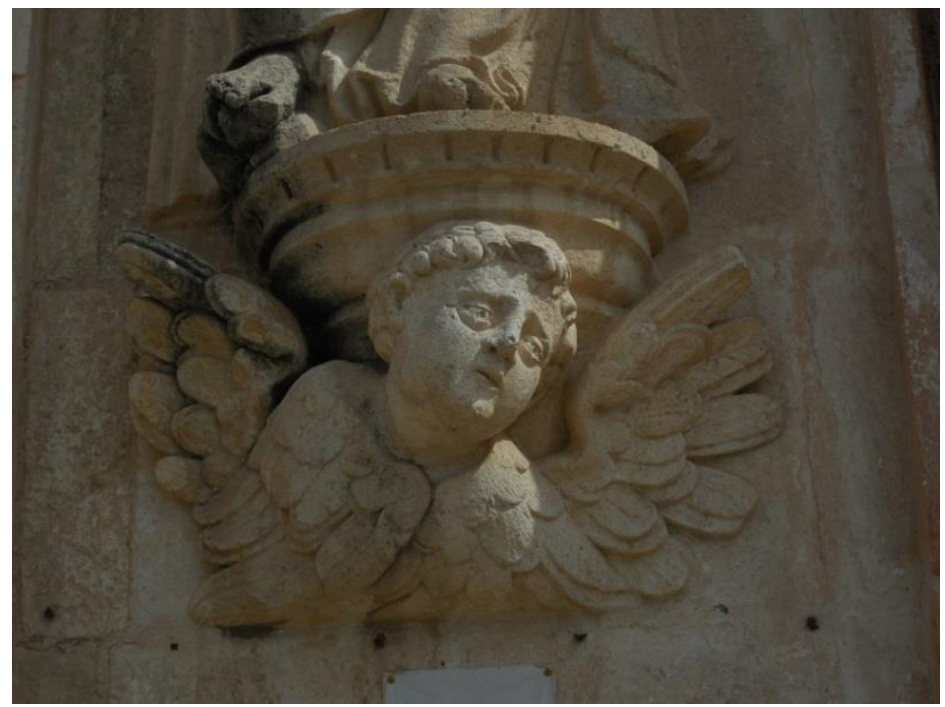

Fig. 20. Querubín esculpido bajo las penas que sostienen a san Pedro y a san Pablo. Fotografía de Fabiola Moreno Vidal.

\subsection{Trisagio}

Decorando el friso de la portada del templo se encuentran las palabras en latín: "SANCTUS DEUS, SANCTUS FORTIS, SANCTUS INMORTALIS", es el llamado Trisagio.

El Trisagio o Trisagion es un cántico que surgió en la cristiandad oriental. Como su propio nombre indica, (trís: tres veces, ágios: santo) consiste en una triple alabanza a la santidad, la fuerza y la inmortalidad de Dios: "Santo Dios, Santo Fuerte, Santo Inmortal, apiádate de nosotros".

$\mathrm{Su}$ origen se remonta al siglo $\mathrm{V}$, durante los catastróficos terremotos que asolaron Constantinopla en 447 y se dice que fue revelado al pueblo para que implorara la misericordia divina. Al hacerlo, los temblores cesaron. Su introducción litúrgica se atribuye a san Proclo, Patriarca de Constantinopla. Pocos años más tarde, en 451, el Concilio de Calcedonia autorizó a todos los fieles a rezarlo para invocar a la Santísima Trinidad en tiempos de calamidad ${ }^{80}$.

El trisagio es un eco del pasaje bíblico en el que los serafines aclaman al Señor: "Santo, Santo, Santo, Señor todopoderoso" (Is 6:3). También en el Apocalipsis se repite "Santo, Santo, Santo es el Señor Dios todopoderoso, el que era, el que es y el que viene" (Ap 4:8).

Partiendo de los trisagios primitivos, los padres hispanos elaboraron nuevos textos con marcado sentido cristológico en los que se resaltan el poder y la realeza de Cristo mediante la utilización de textos del Apocalipsis y como instrumento para combatir las herejías. Seguramente como la portada está relacionada con temas cristológicos tiene mucho sentido la ubicación de este cantico que ensalza la santidad de Cristo.

80 La Ermita. (2010). Trisagio [En línea]. España: Oraciones Hispano-Mozárabes. Disponible en: [http://www.hispanomozarabe.es/ora/ora-tri.htm] consultado el 8 de marzo de 2018 


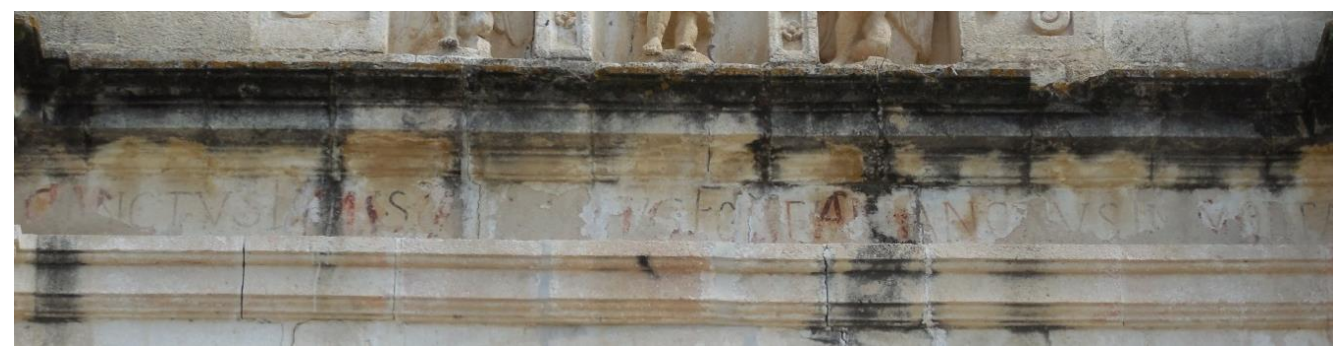

Fig. 21. Palabras en latín que forman el Trisagio, ubicadas en el friso de la portada.

Fotografía de Fabiola Moreno Vidal.

\subsection{Niño Salvador del Mundo}

En la portada de Metztitlán, Jesús aparece representado en la imagen de un niño en actitud erguida, viste túnica sencilla ceñida a la cintura, con la mano izquierda porta el orbe con la cruz y tiene la mano derecha en ademan bendiciente. A esta imagen del Dios Hijo se la conoce como Niño Salvador del Mundo. Se ubica al centro de la cornisa que está sobre el vano de ingreso al templo.

Las primeras representaciones exentas, independientes de cualquier otra escena de infancia de carácter histórico-narrativo y representación mariana o hagiográfica, del Niño Jesús que llegaron al Nuevo Mundo pertenecen a los últimos años del siglo XV y principios del XVI, y la mayor parte de ellas corresponden al Niño Salvador del Mundo. En este modelo, como en otros tantos, se sigue más o menos libremente la iconografía homónima de la versión adulta de esta advocación. Así, el Niño Salvador o Niño Redentor, es otra interpretación de la realeza de Jesús, y que fue plasmada en la figura de Jesús, pero despojada de atributos reales ${ }^{81}$. Lleva en su mano izquierda un orbe o "sfera mundi" como símbolo de su poder sobre el mundo, tiene la mano derecha alzada en ademan de bendecir: elevando los dedos pulgar, índice y medio, mientras que con el pulgar puede sujetar el anular y el meñique. El significado de mostrar los tres dedos se debe a que estos representan a la santísima trinidad ${ }^{82}$. Esta figuración se caracteriza, además, por la ausencia absoluta de toda huella dolorosa. El atributo propio de este tipo iconográfico, es, como ya se mencionó, la esfera del mundo rematada por una pequeña cruz, símbolo alusivo a la proyección universal del acto redentor.

La imagen de Jesús niño es una figura característica de la contrarreforma y la evangelización americana, la Iglesia pronto vio lo provechoso de este modelo para

81 Henares Paque, Vicente, (2008). La iconografía de la imagen exenta del niño Jesús en el arte colonial hispanoamericano. Apuntes para su clasificación, [En línea]. Guatemala: Boletín AFEHC N³5. Disponible en:

[http://afehc-historia-centroamericana.org/index.php?action=fi_aff\&id=1875] consultado el 26 de noviembre de 2014

82 Díaz Hidalgo, Juan Francisco. (2014). La iconografía cristiana, el gesto en el arte cristiano. Los dedos de Cristo, gesto de bendecir. [En línea]. España: El gesto en el arte cristiano. Interpretaciones sobre los gestos manuales. Disponible en:

[https://es.slideshare.net/juandiazhidalgo/el-gesto-de-la-mano-en-la-iconografa-cristiana] consultado el 8 de marzo de 2018 
ponerlo al servicio de su propagandística auspiciado prácticamente por todas las órdenes religiosas. El Niño Jesús se convirtió en un tema iconográfico idóneo en la expresión de valores con clara intención didáctica y moralizadora, con unas formas comunicativas y dialogantes, que ofrecía un magnífico recurso para conectar a los fieles con Cristo y fomentar su relación con él. Se le personifica en su naturaleza humana, ya no divina como en el Románico. El objetivo de esta representación desde inicios de Renacimiento, era transmitir al fiel, desde la perspectiva de la humanidad y debilidad que encierra la infancia, dos ideas fundamentales del plan de Salvación: la evidencia de la grandeza y soberanía de Cristo, y su victoria y triunfo sobre la muerte y el pecado.

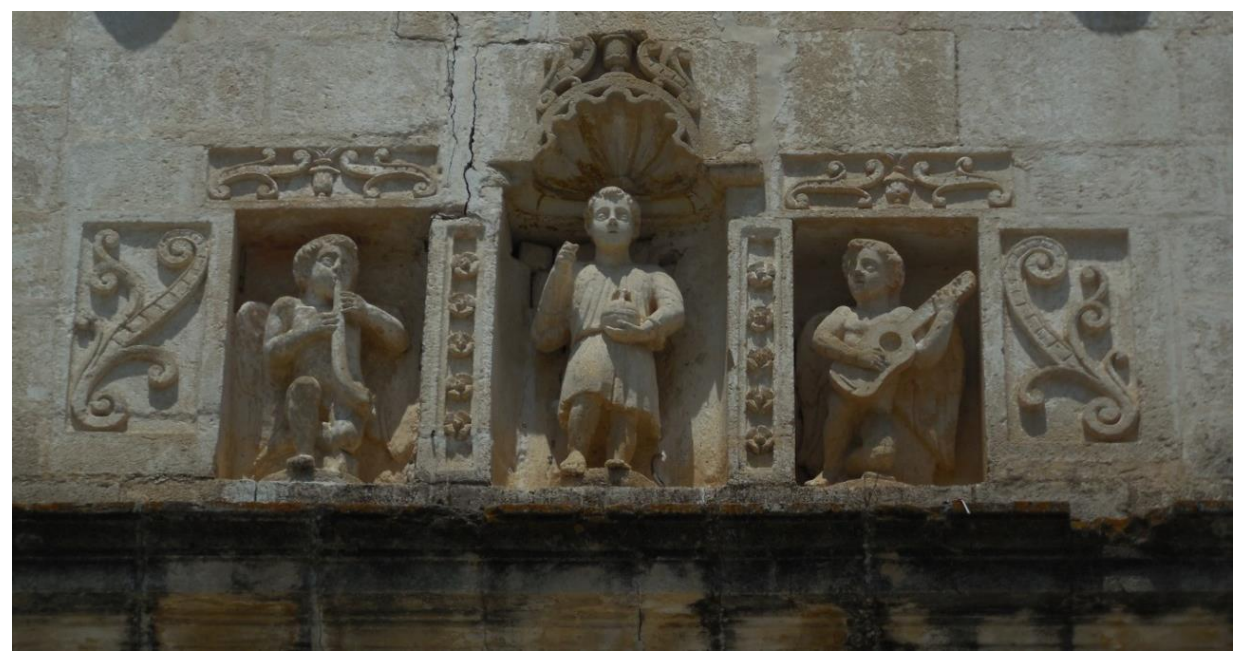

Fig. 22. Niño Salvador del Mundo, flanqueado por cinco flores por lado, acompañado de los ángeles músicos y volutas en forma de S. Fotografía de Fabiola Moreno Vidal.

\subsection{2. Ángeles músicos}

Al centro de la portada y exaltando la presencia del Niño Salvador del Mundo, se ubican dos pequeños angelitos con instrumentos musicales, el de la izquierda (del Niño Jesús) tañe una vihuela y el de la derecha una corneta, ambos instrumentos de origen muy antiguo y de moda en el siglo XVI en la región hispano-mozárabe.

En el antiguo cristianismo se ha otorgado a los instrumentos musicales un determinado simbolismo, así como a las interpretaciones alegóricas de los instrumentos, intentando hacer más fácilmente comprensible los principios dogmáticos. Siendo el valor de los instrumentos más simbólico que musical ${ }^{8 \frac{3}{3}}$.

En las primeras representaciones, donde aparecen santos y ángeles tañendo instrumentos, siendo los más repetidos los cordófonos: citaras, liras, salterios y laúdes de largo mástil. La música responde a la expresión de alegría celestial y a la suavidad inefable y bienhechora que inunda el espíritu de los justos que son admitidos a cantar y aclamar a la Divinidad.

83 González Herranz, Raimundo. "Representaciones musicales en la iconografía medieval”, Anales de Historia del arte, No 8. 67-96, 1998, p. 70 
La conexión de música y espiritualidad en el pensamiento cristiano se funde con los filósofos antiguos y medievales. La Edad Media va a heredar de la antigüedad la convicción de que la música no es una libre creación sino un saber exacto, una aplicación de la teoría matemática. La teoría de la música se consideraba más perfecta que la música misma. Teoría que aspiraba no sólo a ser teoría de la música del hombre sino también de la armonía del universo (de creación divina) ${ }^{84}$.

Fue San Agustín, consignando en tratados el conjunto del saber de su época, quien nos lega el primer tratado «De Musica»; aunque incompleta (solo trata el ritmo), esta obra da impulso a la música cristiana. En general, según San Agustín la música puede ser armónica, orgánica, rítmica, aludiendo respectivamente al canto, en segundo lugar a los instrumentos de viento y en tercer lugar a los de cuerda y percusión. La música seguía considerándose como una propiedad universal de las cosas, por lo que su teoría formaba parte de la filosofía. Esta concepción estaba tan profundamente arraigada y tan divulgada, que las opiniones de los musicólogos y filósofos medievales difieren poco entre si ${ }^{85}$.

Orígenes Adamantius explicaba el significado de los instrumentos del salmo CL: "La cítara es el alma activa que vibra a las órdenes de Cristo; el tamboril es la mortificación de la concupiscencia. El coro es el concierto de las almas razonables diciendo las mismas cosas y de las que están excluidas las cismáticas. Las cuerdas son la consonancia de la voz de las virtudes; el órgano es la iglesia de Dios, que comprende las almas contemplativas y las almas activas" $"$. También San Isidoro alude a la cítara y a sus cuerdas como llamadas del corazón: "Porque así como se mueve el corazón en el pecho, así se mueven las cuerdas de la cítara".

Ahora bien, cuando se habla de un instrumento de cuerda como la cítara, su significado se hace extensible a la lira, arpa, cítola, o inclusive al laúd y la vihuela, todos ellos cordófonos. Lo mismo sucede con los de viento, su valor es simbólico no importando de qué instrumento se trate siempre y cuando sean aerófonos. Los instrumentos van cambiando de acuerdo a la región y la época, como en el caso de Hispania, que tras la invasión musulmana, aparecen en las miniaturas, trompetas sarracenas (añafiles), sobre todo a partir del siglo XI, donde empiezan a sustituir a las tubas, creciendo en longitud y ensanchándose en su parte final ${ }^{87} . \mid$

Otro de los argumentos utilizados es la interpretación alegórica de los instrumentos. Cristo representaba en su sacrificio, la tensión de la carne en la cruz, carne que había sido secada previamente con el ayuno del desierto, a la manera de las cuerdas de la citara hecha de tripas, que se seca y se extiende en una madera cuya imagen podía ser la de la propia cruz ${ }^{88}$. Los timbales con membranas tensas cuyo cuero seco representa la carne incorrupta; las trompetas son la voz de Dios o de los apóstoles; los tubos de órganos son la voz de la predicación y los platillos aluden al júbilo como si de labios se tratase. El propio hombre es un instrumento en manos de Dios que armoniza su cuerpo y alma. San Agustín dice que el salterio (instrumento de

\footnotetext{
$84 \quad$ Ibídem, p. 73

85 Ibídem,

86 Perrot, J., L'orgue. De ses origines hellénistiques á la fin du XIII siécle. Paris 1965, p. 187

87 González Herranz, Raimundo. op.cit, p. 78

88 Gerold, T, Les Péres de l'Eglise et la musique.
} 
cuerda derivado del arpa) representa la elevación del sonido celeste, la predicación del Verbo y los Milagros de origen divino.

Otras veces oponen los instrumentos de cuerda «cithara» a los de viento órgano: San Atanasio (In Psalmos CL) o con San Gregorio: "Puesto que el órgano resuena por sus tubos y la chitara por sus cuerdas, la cíthara puede designar la acción honesta y el órgano la Santa Predicación" 89 .

Dentro de los temas apocalípticos, figuran los ángeles tocando trompas y trompetas (tubas). La función de estos instrumentos sería el de advertir sobre plagas y catástrofes que han de sobrevenir al final de los tiempos o como llamada escatológica de la Resurrección de los muertos y el Juicio Final. Es el instrumento de que se vale la Divinidad para vindicar la justicia. Los ángeles con tubas, son los brazos ejecutores del Altísimo para restablecer el triunfo del Bien, previo castigo del Mal, así renacerá la Jerusalén Celeste, después del castigo de la Babilonia pecadora.

A partir del siglo XII, los instrumentos musicales se ven representados en las grandes portadas románicas, acompañando escenas apocalípticas donde los personajes combinan y equilibran las melodías con arpas, salterios y laudes ${ }^{90}$.

Durante los siglos XIV y XV, podemos encontrar representaciones de ángeles músicos. Los ángeles tocando instrumentos acompañan a las imágenes y advocaciones. Su iconografía aparece en el siglo XIV, acompañando a representaciones marianas y de la natividad y cristicas a partir de la Baja Edad Media, alcanzando en el gótico su máxima expansión. La rápida difusión de los ángeles, fue propiciada por diversos escritos sobre angelología como los de Ramón Llull (1227) o el «Llibre dels Angels», inspirados en Dionisio Aeropagita ${ }^{91}$.

Los ángeles durante la Alta Edad Media se han asociado a las trompetas (tubas) en temas relacionados con el Juicio Final. Durante la Baja Edad Media los ángeles aparecen tocando diversos instrumentos musicales como la flauta, la viola, el arpa y el laúd produciendo una música suave y delicada que transportaba al Paraíso ${ }^{92}$.

Este tipo de representaciones musicales experimenta en España una gran difusión integrando a estos conjuntos instrumentos musicales locales, en los temas de Cristo, este aparece rodeado de ángeles tañendo diversos instrumentos de cuerda como laudes y vihuelas y viento como trompetas (añafiles), chirimías, bombardas y cornetas. Los címbalos o platillos, el pandero con sonajas, las sonajas enfiladas sobre cuerdas y otro posible instrumento ideófono producen sonidos fuertes y ruidosos que nos advierten de la presencia divina.

\subsection{Xonecuilli (xotl, pierna; necuiloa, torcer: Pierna torcida) ${ }^{93}$}

En Metztitlán, encontramos la figura del Xonecuilli a manera de voluta decorada en forma de $\mathrm{S}$, esta se encuentra profusamente distribuida en toda la portada: cerca al vano de ingreso al templo, como capiteles de las columnas y sobre todo por encima de la cornisa que remata el entablamento, se ubica -siempre en pares- como elemento

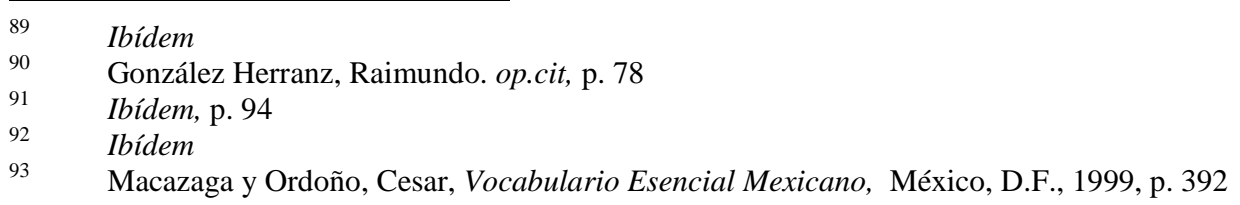


decorativo que soporta los flameros y especialmente, lo encontramos, enmarcando las imágenes de los ángeles músicos y en el doselete que cubre al Niño Salvador del Mundo. Xonecuilli no es solo pie torcido o pierna curva. Tiene otras acepciones, que no alteran su naturaleza simbólica giratoria, como se explicará a continuación. Era un pan ritual en forma de zigzag, Es también un bastón con muescas ofrecido en sacrificios a los dioses y el arma curva o cetro ganchudo que termina en forma espiral, que Quetzalcoatl, en su imagen antropomorfa llevaba en la diestra y cuando este dios se representaba en forma de serpiente, se colocaba ese atributo entre la nariz del ofidio. También tenía forma de xonecuilli la pierna de Tezcatlipoca, perdida en míticos combates ${ }^{94}$. Los nombres que los mexicas daban a sus constelaciones correspondían a objetos habituales en su entorno. Citlaxonecuilli era una constelación importante para los mexicas, formada por 7 estrellas e identificada con la Osa Menor ${ }^{95}$.

Entre los antiguos nahuas el tema de la organización del tiempo diurno y nocturno estaba firmemente ligado a la observación de los astros, del sol durante el día y de las estrellas en la noche, como demuestra el comienzo del capítulo II de los Primeros memoriales de Sahagún. En este texto en náhuatl, dedicado a los cuerpos celestes, la descripción y el dibujo del sol comprenden el recuento de las cinco horas diurnas, mientras que las constelaciones marcaban las siete horas nocturnas, donde el Xonecuilli podía servir como un verdadero reloj celeste, que marcaba la medianoche colocándose en cuatro posiciones distintivas que dividían el año en cuatro partes: hacia abajo en invierno, hacia el este en primavera, hacia arriba en verano y hacia el oeste en otoño ${ }^{96}$. En el folio $282 \mathrm{v}$ de los Primeros memoriales de Fray Bernardino de Sahagún, existe la representación de la constelación Xonecuilli junto con otras constelaciones que tenían importancia para los nahuas. El mismo Sahagún las describe así en su traducción del náhuatl que aparece en la Historia general:

A las estrellas que están en la boca de la Bocina llama esta gente citlalxunecuilli. Píntanlas a manera de una ese revuelta. Siete estrellas dicen que están por sí apartadas de las otras y que son resplandecientes. Llámanles citlalxunecuilli porque tienen seme[ja]nza con cierta manera de pan que hacen a manera de ese, al cual llaman xunecuilli, el cual pan se comía en todas las casas un día del año que se llama xuchílhuitl $^{97}$.

Rendón Ortiz, Gilberto. (2008). Las Constelaciones, un drama cosmogónico en el cielo prehispánico, Edición Especial de Temas Diversos, [En línea]. México: Odisea Revista personal, Año I, No. 1. Disponible en: [http://odiseacd.galeon.com/Odisea2a.html] consultado el 20 de enero de 2016 Galindo Trejo, Jesús. (2015). La Astronomía en el pasado prehispánico de México, p. 37 [En línea]. México: Revista de la Universidad. Disponible en: [http://www.revistadelauniversidad.unam.mx/ojs_rum/files/journals/1/articles/13408/public/1340 8-18806-1-PB.pdf] consultado el 21 de agosto de 2017

96 Kenrick Kruell, Gabriel, Las horas en la vida cotidiana de los antiguos nahuas, Estudios Mesoamericanos, Nueva época, Año 7, Número 13, julio-diciembre 2012, p. 52

97 Sahagún, Fray Bernardino de, Historia general de las cosas de la nueva España, v.II, libro VII, cap. IV, México, editorial Porrúa, 2013, pp.483-484. 


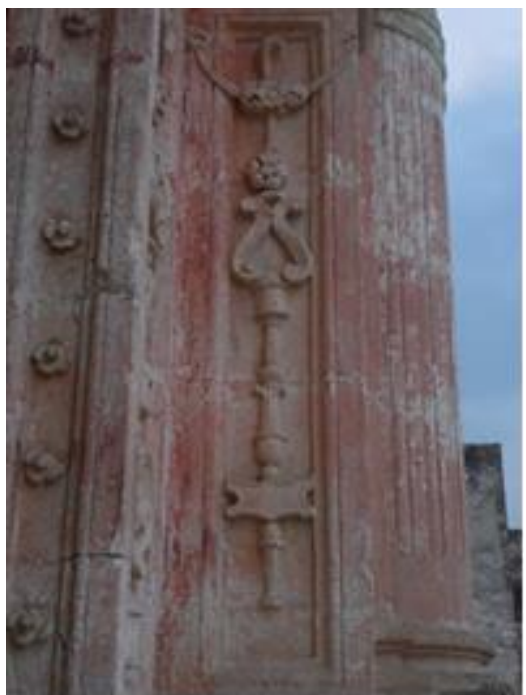

Fig. 23. Volutas en forma de S, representación del xonecuilli. Fotografía de Fabiola Moreno Vidal.

Este pasaje permite una fácil identificación de las estrellas del citlalxonecuilli, ya que son reconocidas por Sahagún con el nombre de Bocina, que según el Diccionario de autoridades es una "constelación celeste en el Hemispherio Septentrional, que consta de cierto número de estrellas, que su positúra retorcida forma una como bocina; y así la llaman los marineros, aunque los Astrónomos la conocen por la Ossa menor" 98 .

Lo interesante de esta constelación en forma de $\mathrm{S}$ es que a la latitud de México nunca se oculta totalmente bajo la línea del horizonte, sino que da vuelta sobre el eje de la estrella polar. Eso significa que su observación servía, para indicar la hora durante la noche. La parte torcida del Xonecuilli está orientada hacia abajo en el solsticio de invierno, hacia el este en el equinoccio de primavera, hacia arriba en el solsticio de verano y hacia el oeste en el equinoccio de otoño. Esta propiedad de la Osa Menor era conocida desde la antigüedad en el mundo europeo y servía a los navegantes para calcular la hora durante las vigilias nocturnas, razón por la cual en los siglos XV y XVI esta constelación se conocía como "Reloj de las Guardas"99. El nombre de Xonecuilli no solo se daba en un cierto tipo de tortilla que se ofrecía en la fiesta de las flores (Xochilhuitl), como refiere Sahagún, sino también al pie cojo de algunas deidades, en particular Tezcatlipoca ${ }^{100}$. la característica del pie cojo o

\footnotetext{
98 Compuesto por la Real Academia Española, Diccionario de la lengua castellana, en que se explica el verdadero sentido de las voces, su naturaleza y calidad, con las phrases o modos de hablar, los proverbios o refranes, y otras cosas convenientes al uso de la lengua. t. I, Madrid, En la Imprenta de la Real Academia Española, por los herederos de Francisco del Hierro, 1737, p.632

99 Comellas, José Luis, El cielo de Colon. Técnicas manuales y astronómicas en el viaje del descubrimiento, Madrid, Athenaica Ediciones Universitarias, 2015, pp. 42-47 Kenrick Kruell, Gabriel, op.cit, p. 52
} 
amputado se debía a que la parte torcida de la Osa Menor se ocultaba bajo el horizonte en las medianoches invernales, coincidiendo con el mito que relata que fue el monstruo de la tierra quien arrancó el pie a Tezcatlipoca ${ }^{101}$.

Es debido a su relación con las deidades acuáticas y terrestres que el xonecuilli era una marca que se aplicaba sobre objetos rituales ligados a los cultos del agua y el pulque $^{102}$, además de su importancia como marcador de tiempo y estaciones del año, se lo representaba en papeles rituales, tocados y mantas. Debido a su multiplicidad de asociaciones para los indígenas, no es de extrañar que la forma del xonecuilli se haya plasmado también en edificios, como es el caso de la portada de Metztitlán.
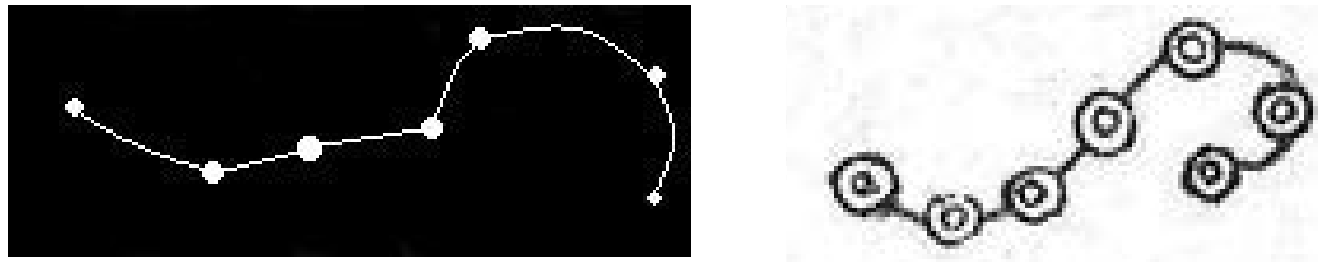

Figs. 24 y 25. Constelación del xonecuilli y su representación por parte de los indígenas en el libro de Fray Bernardino de Sahagún, imagen tomada del artículo de Gabriel Kenrick Kruell7: "Las horas en la vida cotidiana de los antiguos nahuas", Estudios Mesoamericanos, Nueva época, Año 7, Número 13, julio-diciembre 2012, p. 52
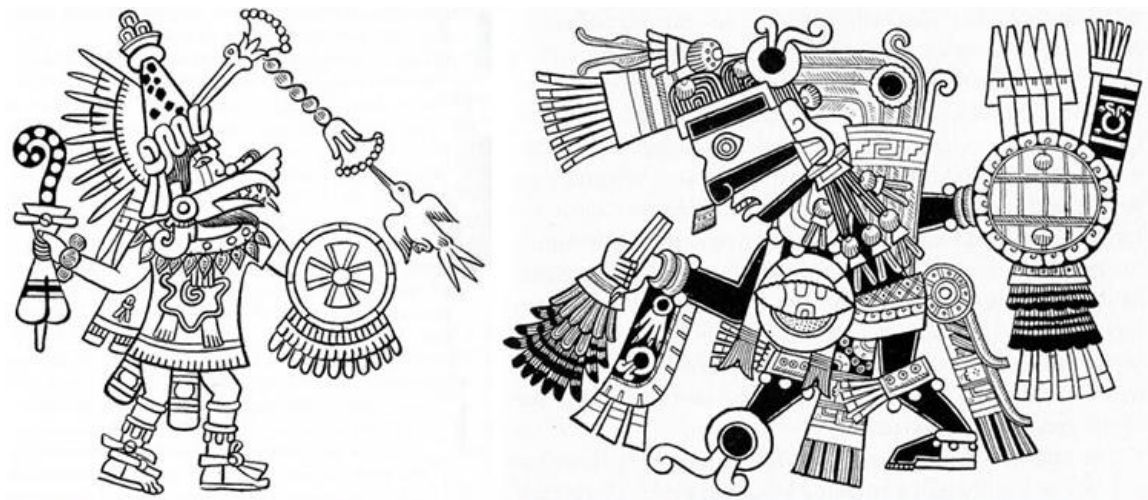

Fig. 26. Quetzalcoatl con su bastón con forma de xonecuilli en el códice Borgia,

Tezcatlipoca con su pie curvo en el códice Magliabechiano. Tomado de http://www.mexicolore.co.uk/aztecs/stories/origin-of-people

\subsection{Citlaltlachtli (juego de pelota estelar)}

Flanqueando la imagen del Niño Salvador del Mundo, se encuentran dos hileras formadas por cinco flores cada una, posiblemente por su número y disposición aludan

Acerca de la amputación del pie de Tezcatlipoca y su relación con el xonecuilli, véase Guilhem Olivier, Tezcatlipoca. Burlas y metamorfosis de un dios azteca, México, FCE, 2004, pp. 413, 418 
a la constelación prehispánica Citlaltlachtli, o juego de pelota estelar; siendo esta una de las constelaciones más célebres, ya que de acuerdo a su aparición y ubicación en el firmamento, los antiguos prehispánicos podían conocer los ciclos del sol ${ }^{103}$. Los mexicas veían al firmamento como un gran juego de pelota celestial donde el disco solar que es la bola de caucho, se movía de un ángulo a otro, como se muestra claramente en el códice Vindobonense ${ }^{104}$. Esto explica el porqué de la ubicación de la imagen de Cristo al centro, ya que este como el astro prehispánico, perece para renacer como el nuevo sol cristiano.

Citlaltlachtli, posiblemente se refiera a Géminis, los gemelos, ya que está conformada por dos líneas de estrellas paralelas, según Sahagún esta constelación era muy importante para los aztecas ${ }^{105}$. Cabe recordar que las flores que conforman las hileras, poseen cuatro pétalos cada una, siendo pequeñas representaciones del NahuiÖlin o quinto sol.
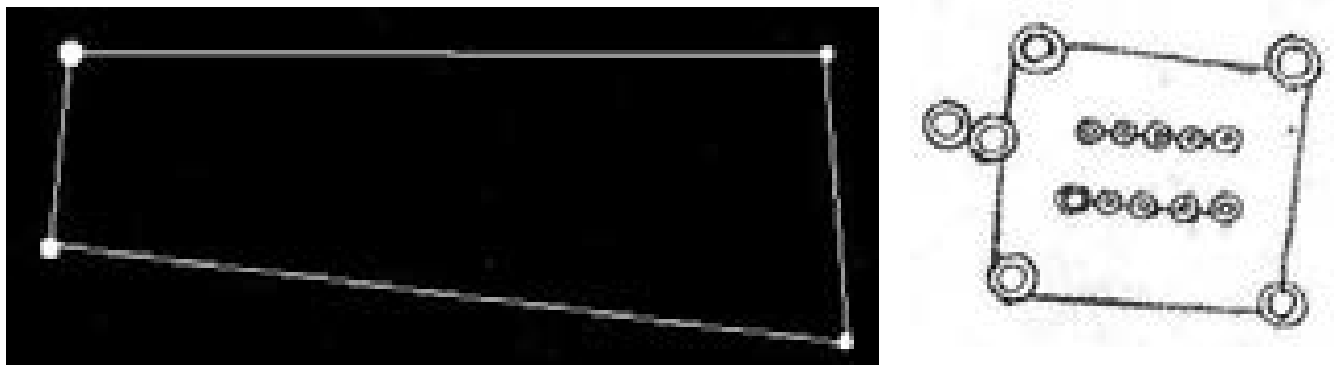

Figs. 27 y 28. Constelación del citlaltlachi y su representación por parte de los indígenas en el libro de Fray Bernardino de Sahagún, imagen tomada del artículo de Gabriel Kenrick Kruell: "Las horas en la vida cotidiana de los antiguos nahuas", Estudios Mesoamericanos, Nueva época, Año 7, Número 13, julio-diciembre 2012, p. 52

En la asociación de flores con astros y la de Cristo con el sol prehispánico, se puede evidenciar un trasfondo de conocimiento y comprensión por parte de los indígenas, ellos supieron interpretar lo que los frailes evangelizadores querían transmitir en cada elemento, en su afán de reemplazar el valor pagano por el cristiano.

En el caso de los pueblos de Mesoamérica, el sol no sólo conformó parte fundamental de sus concepciones cosmológicas y religiosas, sino que, por su importancia en la regulación del ciclo de lluvias y secas - aspecto central en la base económica de sociedades agrícolas como las mesoamericanas - llevó al desarrollo de un calendario de base solar, así como a la observación y registro de las fechas en que el astro luminoso alcanzaba las posiciones solsticiales, equinocciales y pasos cenitales locales. De hecho, se ha considerado que el registro de los extremos solsticiales norte y sur en ambos horizontes es lo que marcaría las cuatro esquinas del mundo o rumbos direccionales, mismos que conforman la base para la elaboración del glifo del nahua-mixteco para movimiento (ollin), en relación con la concepción cuatripartita del Universo. Torres Rodríguez, Alfonso. (1999). La observación astronómica en Mesoamérica. Ciencias 54, abril-junio, 16-27. [En línea]

104 Rendón Ortiz, Gilberto. op.cit

105 Avni, Anthony F., Observadores del cielo en el México antiguo. Fondo de Cultura Económica. 2005. Ciudad de México, p. 57 
En el caso de la portada de Metztitlán los escultores indígenas lograron mostrar ambos, transmitiendo un significado diferente, dependiendo el observador.

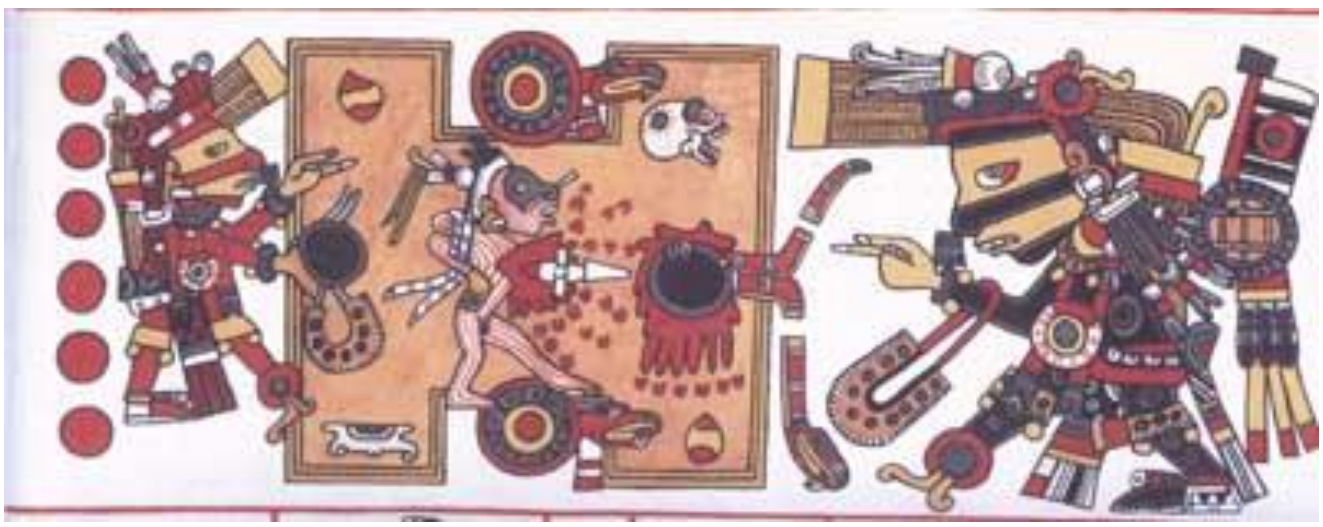

Fig. 29. Representación del juego de pelota estelar, donde Huitzilopochtli y Tezcatlipoca se disputan el sol en el códice Magliabechiano. Tomado de

http://odiseacd.galeon.com/Odisea2a.html

\subsection{Felino}

En la cara interna de la parte correspondiente a la jamba izquierda del vano de ingreso al templo, se puede apreciar, esculpida, la cabeza de un felino, este sostiene con la boca unos lienzos y un racimo de frutas que cuelgan de un listón. Esta figura se ubica del lado izquierdo, viendo de frente la portada. El felino, si bien se parece a los que decoran los capiteles de las columnas, carece de melena por lo que asemeja ser más bien un jaguar.

El jaguar fue uno de los animales más importantes dentro de la cosmovisión prehispánica. En Teotihuacán y en la zona maya, este animal se representaba con atributos de otros animales, como plumas de ave y lengua de serpiente ${ }^{106}$. El cosmos prehispánico estaba conformado por una parte de arriba: celeste, luminosa, diurna, y por una parte de abajo: terrestre, oscura, nocturna; esta última es la que le corresponde al jaguar. El jaguar simbolizaba al sol nocturno y las energías que tienen que ver con el poder de regeneración periódica del cosmos. Los grandes soberanos y los grandes guerreros, incorporaron en su atuendo y sus armas la piel, las garras y los colmillos de jaguar, pues deseaban poseer todo el poder de este gran depredador ${ }^{107}$. Era el compañero del águila por eso, en el Posclásico tardío, a los guerreros valientes se les llamaba cuauhtli-océlotl (águila-jaguar) ${ }^{108}$. Y la elite de la milicia estaba conformada por los Cuauhpipiltin (guerreros águila) y los Ocelopipiltin, (guerreros jaguar) ${ }^{109}$.Era

Museo del Templo Mayor. Simbolismo de los animales prehispánicos, Los Animales y su Simbolismo [En línea]. México: Museo del Templo Mayor. Disponible en [http://www.cultura.gob.mx/videoymultimedia/virtual/templomayor/simbolismo/simbolismo.html ] consultado el 6 de julio de 2017

109 Museo del Templo Mayor, op. cit. Iglesias y Cabrera, Sonia, op. cit. 
el nagual por excelencia de los gobernantes, sacerdotes y de los propios dioses (como Tezcatlipoca). La relación con este dios fue muy estrecha, ya que en los mitos de creación este numen fue el primer Sol, que al ser desplazado por Quetzalcóatl, se convirtió en jaguar. Uno de los mitos prehispánicos cuenta que en Teotihuacán, lugar en el que se crearon el Sol y la Luna, el águila pasó por la hoguera en que se sacrificaron los dioses que quedaron convertidos en astros. Al cruzar el águila, parte de las plumas se le quemaron, por eso es blanca con negro. El jaguar también saltó por encima de la pira sufriendo quemaduras que dejaron su piel cubierta de manchas negras $^{110111}$.

\subsection{6. Águila}

En oposición a la imagen del felino y en la cara interna de la parte correspondiente a la jamba del lado derecho, se puede apreciar, esculpida, la cabeza de un ave cuyo pico sostiene unos lienzos y un racimo de frutas que cuelgan de un listón. Por su representación y por complementariedad simbólica con el felino, se deduce que es un águila.

Como símbolo religioso, para los prehispánicos, el águila fue una epifanía solar, y representó principalmente el carácter guerrero, concebido como una misión sagrada, la fuerza, la agresividad, la valentía, el dominio del espacio. Pero también representó la muerte que genera la vida del universo, el sacrificio que el hombre hace de sí mismo para sustentar a los dioses con su propia sangre.

Esta obsesión por el sacrificio y la guerra culmina con la representación del águila, que es una imagen del sol. En la simbología de los mexicas el águila es el doble del Sol: encarna su faz diurna y el movimiento ascendente hacia el cenit. Es el ave solar por excelencia, un depredador, un cazador. La imagen que representa el águila devorando pájaros o corazones alude a la victoria del Sol sobre sus enemigos y expresa el triunfo de los guerreros sobre los antiguos pueblos agrícolas. Era un emblema cuyos símbolos reiteraban la legitimidad de la ocupación territorial, la unidad del pueblo mexica y la obsesión por la grandeza futura ${ }^{112}$.

Al Águila Solar se le ofrendaba el corazón y la sangre obtenidos en sacrificios humanos, después que el sacerdote los extraía de una de las múltiples víctimas. A continuación, los colocaban en un recipiente llamado quauhxicalli (cajete de águila), para que el sacrificado deviniera en "Hombre-Águila" y el corazón en "Tuna de Águila”. La sangre alimentaba al Águila Solar, de esta manera el Sol podía continuar con su tarea itinerante de todos los días, gracias al chalchíhuatl (líquido precioso). Huichilopochtli, el rey Sol, luchó contra sus hermanos la Luna y las Estrellas y los venció, gracias a lo cual podía salir cada mañana como Cuautlehuánitl (águila que

\footnotetext{
110 Museo del Templo Mayor, op. cit.

111 Este apartado se extrajo de las páginas 92, 93, 94 del artículo "Análisis iconográfico de la portada del Templo de San Francisco de Asís en Tepeapulco Hidalgo", publicado por la autora en la revista Eikón Imago No. 12 (2017 / 2) ISSN-e 2254-8718

112 Florescano, Enrique, Ensayos Fundamentales, México, Editorial Taurus, 2009, p. 276
} 
asciende), y desaparecer por el poniente como Cuauhtémoc (águila que desciende) ${ }^{113}$. En su descenso se convertía en ocelote, símbolo animal de las fuerzas nocturnas, de los poderes de la oscuridad y la muerte. Así el águila y el ocelote, las dos epifanías animales del Sol, encarnaron entre los mexicas a los contrarios cósmicos: luz y oscuridad, vida y muerte, razón e irracionalidad ${ }^{114}$. Ambos estaban estrechamente vinculados en las órdenes militares cuya elite estaba dividida en guerreros águila y guerreros jaguar.

Todos los atributos que los pueblos de la antigüedad atribuían al águila fueron asimilados por el cristianismo primitivo convirtiéndose en una excelente imagen de Cristo: Aquila Christus, por lo que sus representaciones poseen una variedad significados.
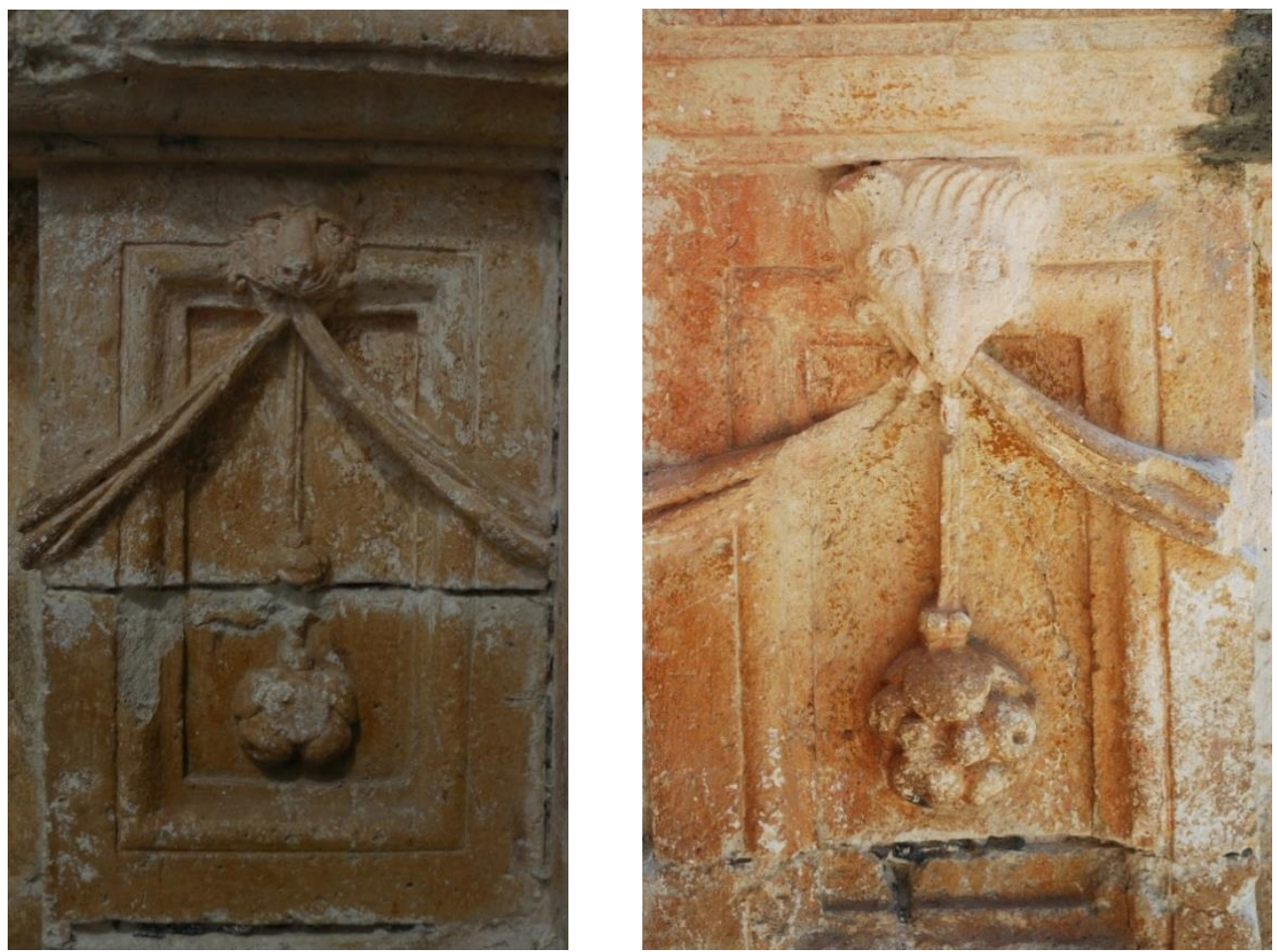

Fig. 30. Imagen de la cabeza de un felino en el pedestal izquierdo de la portada.

Fotografía de Fabiola Moreno Vidal.

Fig. 31. Imagen de la cabeza de un ave en el pedestal derecho de la portada.

Fotografía de Fabiola Moreno Vidal.

113

Iglesias y Cabrera, Sonia. (2015). El Águila y los Mexicas [En línea]. México: Komoni.mx. Disponible en [http://komoni.chemisax.com/el-aguila-y-los-mexicas/] consultado el 16 de julio de 2017

114 De la Garza, Mercedes, op. cit., p.109. 
El papel conductor de las almas "hacia los dioses celestiales" que los antiguos daban al águila fue conservado con muy buen criterio para el Águila-Cristo, pues solo es Él, el redentor, quien conduce y eleva las almas al cielo. También se reconocía a Jesucristo como autor de la vida, al Creador, por lo que el Águila-Cristo que lleva la vida en su boca, es el verbo creador, el verbo y la vida ${ }^{115}$.

A causa de la creencia de que el águila en su vejez se acercaba tanto al sol que se le calcinaban las plumas y la carne hasta secarse, pero que al regresar a la tierra se zambullía por tres veces en el agua viva de una fuente y salía de ella regenerada y rejuvenecida, los cristianos la interpretaron como la resurrección de Cristo de entre los muertos y al mismo tiempo como la resurrección del cristiano ${ }^{116}$ a través del bautismo $^{117}$.

\section{Reflexión final}

La portada de Metztitlán ofrece una sorprendente cantidad de elementos simbólicos asimilados por el cristianismo, cuyo significado, en muchos casos, es tan antiguo que se remonta a los pueblos de Persia, Mesopotamia y el norte de África. Por otro lado, en la portada también se encuentran las representaciones simbólicas prehispánicas de constelaciones y animales representativos en la cosmovisión indígena.

En la portada de Metztitlán los elementos decorativos han sido dispuestos cuidadosamente en números determinados, estas no son arbitrarias, sino que encierran significados en sí mismos y están relacionados con la creación de las cosas por Dios.

Es muy interesante entender el sentido que existe en la ubicación de los elementos simbólicos cristianos y los prehispánicos en la portada y la relación simbólica que existe entre ambos, lo que denota un conocimiento por parte de los indígenas talladores acerca del mensaje que pretendían transmitir los frailes evangelizadores. Un ejemplo de esto se ve reflejado en la ubicación del Niño Salvador del Mundo al centro de la portada, siendo el nuevo sol o centro del universo, rodeado de constelaciones prehispánicas como son el xonecuilli y el citlaltlachi.

La importancia de la constelación del xonecuilli como marcador del tiempo, para los indígenas, se ve reflejada en la portada de Metztitlán ya que esta figura se repite como ninguna otra en varias partes de esta. La constelación del citlaltlachi está formada por flores de cuatro pétalos, imagen del nahui ollin en la cosmovisión indígena y por flores, representación de las estrellas sobre la tierra dentro del enfoque occidental.

Por lo tanto la portada de Metztitlán es una muestra del sincretismo cultural que se dio en la Sierra Alta de Hidalgo y del conocimiento por parte de los indígenas del mensaje simbólico que pretendían transmitir los frailes evangelizadores.

\footnotetext{
$115 \quad$ Ibídem p. 75,81

$116 \quad$ Ibídem p. 83

117 Este apartado se extrajo de las páginas 86, 87, 88, 89, 90, 91 del artículo “Análisis iconográfico de la portada del Templo de San Francisco de Asís en Tepeapulco Hidalgo”, publicado por la autora en la revista Eikón Imago No. 12 (2017 / 2) ISSN-e 2254-8718
} 


\section{Bibliografía.}

Acuña, René (ed.), "Relación de la Alcaldía Mayor de Metztitlán y su Jurisdicción, 1579”, en Relaciones Geográficas del siglo XVI: México. Tomo segundo. UNAM. México. 1986. $226 \mathrm{p}$.

Arendzen, John. (2005). “Cherubim”. Fuente: The Catholic Encyclopedia. Vol. 3. [En línea]. USA: Ecwiki encyclopedia católica on line. Disponible en: [http://ec.aciprensa.com/wiki/Querub\%C3\%ADn] consultado el 25 de enero de 2018

Artigas, Juan Benito, Metztitlán Hidalgo: Arquitectura del siglo XVI, Universidad Nacional Autónoma de México, 1996, 188 p.

Avni, Anthony F. Observadores del cielo en el México antiguo. Fondo de Cultura Económica. 2005. Ciudad de México, 517 p.

Ayuntamiento Digital. (2014). Convento de los Santos Reyes. [En línea]. México: Honorable Ayuntamiento Municipal de Metztitlán. Disponible en [http://metztitlan.gob.mx/turistico/Contenido.php?seccion=2\&lat=681]

Beker, Udo, Enciclopedia de los símbolos. Ed. Swing, Barcelona, 2008, 446 p.

Cabral Pérez, Ignacio. Los símbolos cristianos, Ed. Trillas. México, 1995, 289 p.

Campo de elche. (2017). Historia de la Granada fruta. [En línea]. España. Disponible en:

[https://campodeelche.com/historia-de-la-granada-fruta-salud-en-cada-grano/] consultado el 10 de agosto de 2017

Cantú Treviño, Sara, La vega de Metztitlán en el estado de Hidalgo. Sociedad Mexicana de Geografía y Estadística, t. LXXI, núm. 1-3, México, 1953, 284 p.

Carrasco, Pedro, Los Otomíes. Cultura e Historia prehispánica de los pueblos mesoamericanos de habla otomiana, México, Gobierno del Estado de México, 1986

Carreón Blaine, Emilie, El Olli en la plástica mexica. El uso de hule en el siglo XVI, Instituto de Investigaciones Estéticas, UNAM, México, 2006, 239 p.

Cerrillo, Antonio. (2010). Culturas antiguas, religiones, creencias e ideologías han utilizado la rosa como emblema [En línea]. España: La Vanguardia Libros. Disponible en: [http://www.lavanguardia.com/libros/20100423/53913545357/culturas-antiguasreligiones-creencias-e-ideologias-han-utilizado-la-rosa-como-emblema.html] consultado el 25 de enero de 2018

Comellas, José Luis, El cielo de Colon. Técnicas manuales y astronómicas en el viaje del descubrimiento, Madrid, Athenaica Ediciones Universitarias, 2015, 344 p.

Charbonneau-Lassay, L., "El bestiario de Cristo, simbolismo animal en la antigüedad y la edad media”. Vol. I - II, traducción de Francesc Gutiérrez, Barcelona, Sophia Perennis, 1997, $515 \mathrm{p}$.

Díaz Hidalgo, Juan Francisco. (2014). La iconografía cristiana, el gesto en el arte cristiano. Los dedos de Cristo, gesto de bendecir. [En línea]. España: El gesto en el arte cristiano. Interpretaciones sobre los gestos manuales. Disponible en: [https://es.slideshare.net/juandiazhidalgo/el-gesto-de-la-mano-en-la-iconografacristiana] consultado el 8 de marzo de 2018 
Documental fotográfico en técnicas alternativas de la arquitectura del siglo XVI de Hidalgo. (2012). Ex Conventos de Hidalgo México [En línea]. México. Disponible en [http://132.248.9.195/pd2008/0624429/A6.pdf] consultado el 25 de enero de 2017

El Nuevo Ágora. (2008). Las Confesiones de San Agustín, [En línea]. México: Disponible en:[http://elnuevoagora.blogspot.mx/2008/05/las-confesiones-de-sanagustn.html] consultado el 10 de agosto de 2017

Espinosa Spíndola, Gloria, Arquitectura de la Conversión y Evangelización en la Nueva España durante el Siglo XVI, Universidad de Almería, Servicio de Publicaciones 1999

Esteban Lorente, Juan Francisco, Tratado de Iconografía, Madrid, Editorial Istmo, 2002

Fernández, Justino, Arte Mexicano. De sus orígenes a nuestros días, México, Editorial Porrúa, 1975, $410 \mathrm{p}$.

Filo Zitlalxochitzin: "El Nahui-Ollin plasmado en el Calendario Azteca y en la Pintura Guadalupana: el universo de la cultura náhuatl cifrado en un símbolo", Dec 7, 2013; disponible en

[http://www.tonantzinguadalupe.org/el-nahui-ollin-plasmado-en-el-calendarioazteca-y-en-la-pintura-guadalupana/] consultado el 4 de agosto de 2015

Florescano, Enrique, Ensayos Fundamentales, México, Editorial Taurus, 2009

Iglesias y Cabrera, Sonia. (2015). El Águila y los Mexicas [En línea]. México: Komoni.mx. Disponible en [http://komoni.chemisax.com/el-aguila-y-los-mexicas/] consultado el 16 de julio de 2017

Gadea Saguier Christian. (2006). La granada, fruto de la armonía [En línea]. Paraguay: blog Los Arquitectos. Disponible en:[http://losarquitectos.blogspot.mx/2006/04/la-granada-fruto-de-la-armona.html] consultado el 10 de agosto de 2017

Galindo Trejo, Jesús. (2015). "La Astronomía en el pasado prehispánico de México", p. 37 [En línea]. México: Revista de la Universidad. Disponible en: [http://www.revistadelauniversidad.unam.mx/ojs_rum/files/journals/1/articles/1340 8/public/13408-18806-1-PB.pdf] consultado el 21 de agosto de 2017

Gelsomino del Guercio. (2016). ¿Qué significa la granada en la Biblia?. [En línea]. Italia: Aleteia. Disponible en: [https://es.aleteia.org/2016/10/14/que-significa-lagranada-en-la-biblia/2/] consultado el 10 de agosto de 2017

Gerhard, Peter, Geografía histórica de la Nueva España, 1519-1821, México, Universidad Nacional Autónoma de México, 1986, 496 p.

Municipios.mx. (2018). Hidalgo. Metztitlán. [En línea]. México: Todos Los Municipios de México. Disponible en [http://www.municipios.mx/hidalgo/metztitlan/] consultado el 23 de abril de 2018.

Gobierno del Estado de Hidalgo. (2002). Enciclopedia de los Municipios de México. Estado de Hidalgo. Metztitlán. Medio Físico. [En línea]. México: Instituto Nacional para el Federalismo y el Desarrollo Municipal. Disponible en [http://intranet.e-hidalgo.gob.mx/enciclomuni/municipios/13037a.htm] consultado el 23 de abril de 2018.

González Herranz, Raimundo. "Representaciones musicales en la iconografía medieval ", Anales de Historia del arte, No 8. 67-96, 1998 
Grijalva, Juan de. Crónica de la Orden de N. P. S. Agustín en las Provincias de la Nueva España. Editorial Porrúa. México. 1985, 543 p.

Henares Paque, Vicente, (2008). La iconografía de la imagen exenta del niño Jesús en el arte colonial hispanoamericano. Apuntes para su clasificación, [En línea]. Guatemala: Boletín AFEHC $\mathrm{N}^{\circ} 35$. Disponible en: [http://afehc-historiacentroamericana.org/index.php?action=fi_aff\&id=1875] consultado el 26 de noviembre de 2014

Hipona, Agustín de. (2007). Confesiones. Libro II. Adolescencia ociosa y culpable en Tagaste, a los dieciséis años (369-370) [En línea]. España: Editorial Libros en Red, $2007 . \quad$ Disponible en: [http://www.iesdi.org/universidadvirtual/Biblioteca_Virtual/Confesiones\%20de\%2 OSan\%20Agustin.pdf] consultado el 16 de agosto de 2017 http://www.corazones.org. (2017). El pez, símbolo cristiano [En línea]. España. Disponible en: [http://es.catholic.net/op/articulos/53274/cat/66/el-pez-simbolocristiano.html] consultado el 5 de septiembre de 2017

Interempresas Media, S.L. (2017). Melocotón Origen y Producción. [En línea]. México: Frutas \& Hortalizas. Disponible en: [http://www.frutashortalizas.com/Frutas/Origen-produccion-Melocoton.html] consultado el 10 de agosto de 2017

José. (2007). Fechas clave de Jesús [En línea]. España: Textos de la historia de la Iglesia. Disponible en:

[http://textoshistoriadelaiglesia.blogspot.mx/2007/12/fechas-clave-de-jess.html] consultado el 15 de septiembre de 2017

Morazán. (2016). 27 datos curiosos del número 27 [En línea]. Honduras: centrodeamerica.net Disponible en: [ http://centrodeamerica.net/27-datos-curiososdel-numero-27/] consultado el 15 de septiembre de 2017

Kenrick Kruell, Gabriel, "Las horas en la vida cotidiana de los antiguos nahuas ", Estudios Mesoamericanos, Nueva época, Año 7, Número 13, julio-diciembre 2012

Lameiras, José, Metztitlán. Notas para su etnohistoria. Tesis de Maestría en Ciencias Antropológicas. México, Escuela Nacional de Antropología e Historia, INAH, $1969,342 \mathrm{p}$.

La Ermita. (2010). Trisagio [En línea]. España: Oraciones Hispano-Mozárabes. Disponible en: [http://www.hispanomozarabe.es/ora/ora-tri.htm] consultado el 8 de marzo de 2018

Lorenzo Monterrubio, Carmen, El lugar de la luna, Metztitlán en el siglo XV, México, Instituto de Artes, Universidad Autónoma del Estado de Hidalgo, 2003, 164 p.

Lourdes, María. (2010). ¿Por qué es el pez un símbolo cristiano? [En línea]. España. Disponible en: [http://infocatolica.com/blog/sarmientos.php/1004231158-ipor-quees-el-pez-un-simbolo] consultado el 5 de septiembre de 2017

Loyal, Simón. (2012). El Simbolismo de la Rosa. [En línea]. España: Antroponomicon. Disponible en: [https://antroponomicon.wordpress.com/2012/01/05/el-simbolismo-de-la-rosa/] consultado el 25 de enero de 2018

Lurker, Mamfred, El Mensaje de los Símbolos, mitos, culturas y religiones, Barcelona, Herder, 2000, 367 p. 
Macazaga y Ordoño, Cesar, Vocabulario Esencial Mexicano, México, D.F., 1999, $389 \mathrm{p}$.

Manzarbeitia Valle, Santiago. (2015). San Pablo. [En línea]. España: [http://webs.ucm.es/centros/cont/descargas/documento35214.pdf] consultado el 24 de enero de 2018

Monterrosa Prado, Mariano. Repertorio de Símbolos Cristianos. INAH., México, 2004, 452 p.

Moreno, Juan Carlos. (2016). Etimología de Rosa [En línea]. Chile: Etimologías. Disponible en: [http://etimologias.dechile.net/?rosa] consultado el 25 de enero de 2018

Museo del Templo Mayor. Simbolismo de los animales prehispánicos, Los Animales y su Simbolismo [En línea]. México: Museo del Templo Mayor. Disponible en [http://www.cultura.gob.mx/videoymultimedia/virtual/templomayor/simbolismo/si mbolismo.html] consultado el 6 de julio de 2017

Numero de. (2012). Número 10 en la Biblia [En línea]. España: Numero de. Disponible en: consultado el 29 de marzo de 2018

Odisea Revista personal, Año I, No. 1. Disponible en: [http://odiseacd.galeon.com/Odisea2a.html] consultado el 20 de enero de 2016

Perrot, J., L' orgue. De ses origines hellénistiques á la fin du XIII siécle. Paris, J. Picard, 1965, $434 \mathrm{p}$.

Real Academia Española, Diccionario de la lengua castellana, en que se explica el verdadero sentido de las voces, su naturaleza y calidad, con las phrases o modos de hablar, los proverbios o refranes, y otras cosas convenientes al uso de la lengua. t. I, Madrid, En la Imprenta de la Real Academia Española, por los herederos de Francisco del Hierro, 1737, 656 p.

Rendón Ortiz, Gilberto. (2008). Las Constelaciones, un drama cosmogónico en el cielo prehispánico, Edición Especial de Temas Diversos, [En línea]. México:

Rubial, Antonio. El Convento Agustino y la Sociedad Novohispana (1553-1630). UNAM. México, 1989, 343 p.

Sahagún, Fray Bernardino de, Historia general de las cosas de la nueva España, v.II, libro VII, cap. IV, México, editorial Porrúa, 2013

Sanando La Tierra. (2016). Pomegranate - Simbolismo De La Granada En La Biblia - Beneficios Para La Salud - Presión - Colesterol [En línea]. USA. Disponible en: [https://www.sanandolatierra.org/pomegranate-simbolismo-de-la-granada-en-labiblia-beneficios-para-la-salud-presion-colesterol/] consultado el 10 de agosto de 2017

Secretaría de Gobernación, Gobierno del Estado de Hidalgo. (2010). Enciclopedia de los municipios y Delegaciones de México, Estado de Hidalgo [En línea]. México: Instituto para el Federalismo y el Desarrollo Municipal. Disponible en [http://www.inafed.gob.mx/work/enciclopedia/EMM13hidalgo/municipios/13037a .html] consultado el 14 de agosto de 2017.

Tribu Arcoíris: "El Quinto Sol: Profecía Azteca y Otras Culturas", 26 de noviembre de 2011; disponible en [http://tribuarcoiris.blogspot.mx/2011/02/quinto-sol-mayasaztecas-mitos.html] consultado el 20 de enero de 2016

Wikipedia. (2017). Rosa. [En línea].USA. Disponible en: 
https://es.wikipedia.org/wiki/Rosa consultado el 25 de enero de 2018

Tu fe católica. (2011). Iconografía de los apóstoles. Las imágenes de los doce apóstoles. [En línea]. Colombia: Los Apóstoles. Disponible en:[ http//. tufecatolica.com] consultado el 24 de enero de 2018

Tochtli. (2006). Meztli Azul [En línea]. México: Metztitlan, Hidago. Disponible en http://metztliazul.blogspot.mx/2006/12/metztitlan-hidalgo-mxico.html

Tresidder, Jack, Diccionario de los símbolos, Ed-tomo, México, 1999, 256 p.

Visitarb Madrid. (2017). Simbología de la Granada [En línea]. España: Recorridos botánicos por los jardines y espacios verdes de Madrid. Disponible en:[http://www.visitarb.com/simbologia-la-granada/] consultado el 10 de agosto de 2017

Uchamny, Eva A. "De algunos cristianos nuevos en la conquista y colonización de la Nueva España”. Estudios de Historia Novohispana. Vol. VIII. UNAM. México. 1985, 477 p.

Urquiza Ruiz, Teodoro, Símbolos en el arte cristiano, Breve diccionario ilustrado, Ed. Sembrar, España, 2012

Vallés, Tere. (2018). Pedro y Pablo, Santos. [En línea]. España: Solemnidad Litúrgica. Disponible en:[http://es.catholic.net/op/articulos/32203/pedro-y-pablo-santos.html] consultado el 24 de enero de 2018

Vergara, Vergara, José, Convento de los Santos Reyes Metztitlán, convento de Santa María Molango, México, Gobierno Del Estado De Hidalgo, colección hidalguense N 9 Editorial Mina Pachuca Hidalgo, 2012, 209 p.

Victoria, José Guadalupe. Arte y Arquitectura en la Sierra Alta. Siglo XVI. UNAM. México. 1985. 183 p. 